\title{
SHOULD JUDGES JOIN IN? A NORMATIVE STUDY OF JOINT JUDGMENTS IN SELECTED AUSTRALIAN INTERMEDIATE APPELLATE COURTS
}

\author{
JAMES ANTHONY JOHN DUNN*
}

\begin{abstract}
In the light of both the Chief Justice of the High Court of Australia Susan Kiefel's extrajudicial comments on the 'institutional responsibility' of appellate courts to decide cases by joint judgment where possible, and literature that indicates an increase in the expression of reasons through joint judgment in the High Court of Australia since the beginning of former Chief Justice Robert French's tenure, there has been much debate on the desirability of joint judgments. In this article, I present empirical information on selected New South Wales and federal intermediate appellate court judgment writing practices from 2009 to 2019. I do so to address former President of the New South Wales Court of Appeal Margaret Beazley's 'dalliance on a curiosity' concerning both joint judgment trends and whether Australian intermediate appellate courts should, given the example set by certain Justices of the High Court, preference joined reasons to separate individual concurrences.
\end{abstract}

\section{INTRODUCTION}

In 2014, Justice Susan Kiefel of the High Court of Australia ('HCA') wrote that '[i]t is the institutional responsibility of the members of a [multi-member] court' to 'reduce the number of judgments in any matter' and to strive to provide joint judgment. ${ }^{2}$ Shortly after her elevation to Chief Justice of the HCA in 2017, her Honour again emphasised the precedential and institutional benefit of joint judgments in encapsulating 'the voice of the Court' rather than 'the sound of self'

\footnotetext{
BCom, LLB (Hons 1) (UNSW). My gratitude goes to Professor Andrew Lynch for his wisdom, insightful guidance, and excellent supervision of this research whilst then Acting Dean of the University of New South Wales Faculty of Law. I wish to thank my friend Andrei Smolnikov for his support and encouragement, and the anonymous peer reviewers for their comments. Any errors are my own.

President Margaret Beazley, 'Judgment Writing in Final and Intermediate Courts of Appeal: "A Dalliance on a Curiosity"' (2015) 27(9) Judicial Officers' Bulletin 79.

Justice Susan Kiefel, 'The Individual Judge' (2014) 88(8) Australian Law Journal 554, 560 ('The Individual Judge').
} 
through the alternate practice of writing separate concurring reasons. ${ }^{3}$ Chief Justice Kiefel's push towards a greater use of joint judgments, whereby some or all judges in a matter ascribe their names equally to a set of reasons, 4 builds upon that of her immediate predecessor, Chief Justice Robert French, who emphasised the 'very important place for joint judgments' in 'authoritatively and clearly stat[ing] the law'. ${ }^{5}$

Lynch and Williams' empirical studies of HCA judgment writing practices highlight a trend towards greater joined expression under Chief Justice Kiefel and Chief Justice French's leadership. Lynch acknowledges that the HCA is not immune from 'the tension between judicial emphasis on the institution on one hand and the individual on the other in the process of decision-making'. ${ }^{6}$ However, Lynch and Williams' data, which captures information on all HCA matters on an annual basis and has been collected since 2003,7 illustrates that the Kiefel Court clearly 'striv[es] for consensus ... in order to meet the institutional aspirations' to expand joint judgment usage. ${ }^{8}$ While HCA unanimity rates

Chief Justice Susan Kiefel, 'Judicial Methods in the 21 ${ }^{\text {st }}$ Century' (Speech, Supreme Court of New South Wales Oration, 16 March 2017) 8-9 <https://cdn.hcourt.gov.au/assets/publications/ speeches/current-justices/kiefelj/KiefelCJ16Mar2017.pdf> ('Judicial Methods in the 21 $1^{\text {st }}$ Century'). The scope of 'joint judgment' is contested. One view, and the view to which this article proceeds under, is that a joint judgment can describe any single judgment with two or more justices' names ascribed to it equally, including unanimous joint judgments (or judgments of the Court). See, eg, Andisheh Partovi et al, 'Addressing "Loss of Identity" in the Joint Judgment: Searching for "The Individual Judge" in the Joint Judgments of the Mason Court' (2017) 40(2) University of New South Wales Law Journal 670, 692 where the authors use the term 'unanimous joint judgment'; Michael Coper, 'Concurring Judgments' in Tony Blackshield, Michael Coper and George Williams (eds), The Oxford Companion to the High Court of Australia (Oxford University Press, 2001) 129, 129 ('Concurring Judgments') where Coper defines joint judgments as including judgments 'of the Court as a whole or of a majority'; Damien Carrick, 'Retiring Chief Justice Robert French', The Law Report (ABC Radio National, 13 December 2016) < https://www.abc.net.au/radionational/programs/ lawreport/retiring-chief-justice-robert

-french/8105828> where Chief Justice Robert French said 'then that becomes a joint judgment of the two of them. And sometimes you'll get a cascade of those concurrences, so that you'll end up with a joint judgment sometimes of everybody'. See generally Justice Patrick Keane, 'The Idea of the Professional Judge: The Challenges of Communication' (Speech, Judicial Conference of Australia Colloquium, 11 October 2014） <https://www.hcourt.gov.au/assets/publications/ speeches/current-justices/keanej/The_Idea_of_the_Professional_Judge_-_JCA_Colloquium

Noosa_October_2014_-_Justice_P_A_Keane.pdf $>$. The other view is that of Chief Justice

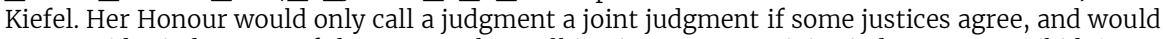
not consider judgments of the Court, where all justices agree, as joint judgments. See ibid 6. See also Justice Susan Kiefel, 'Reasons for Judgment: Objects and Observations' (Speech, Sir Harry Gibbs Law Dinner, 18 May 2012) 4 <https://www.hcourt.gov.au/assets/publications/ speeches/current-justices/kiefelj/kiefelj-2012-05-18.pdf>.

Carrick (n 4).

Andrew Lynch, 'The High Court on Constitutional Law: The 2019 Statistics' (2020) 43(4) University of New South Wales Law Journal 1226, 1239 ('2019 Statistics').

For their first article in their annual series, see Andrew Lynch and George Williams, 'The High Court on Constitutional Law: The 2003 Statistics' (2004) 27(1) University of New South Wales Law Journal 88.

Andrew Lynch and George Williams, 'The High Court on Constitutional Law: The 2018 Statistics' (2019) 42(4) University of New South Wales Law Journal 1443, 1455 ('2018 Statistics'). 
fluctuate over time, ${ }^{9}$ possibly due to the inherent difficulty of consistently achieving complete consensus, Lynch and Williams' statistical information ultimately demonstrates a 'trend towards an "institutional voice"', ${ }^{10}$ underpinned by the very high prevalence of judges joining together in plurality in situations where unanimity is not possible.

Former President of the New South Wales Court of Appeal ('NSWCA') Margaret Beazley described the HCA's movement towards joint judgments as part of a 'discernible shift in [its] writing process'. ${ }^{11}$ Indeed, Smyth and Narayan observed that 'separate and dissenting opinions have been a fairly regular feature of the [High] Court's decision making' from 1906 to their paper's time of publication in 2004, with joint judgments having a sporadic and inconsistent role in court practice throughout that period. ${ }^{12}$ However, President Beazley asked whether the HCA's trend, 'assuming it is a trend', towards increased joint expression has normative 'implications' for intermediate appellate courts. In particular, she questioned whether intermediate appellate court judgment writing should remain more 'discursive and detailed' through, inter alia, a practice of writing separate concurring judgments in multi-member matters, or whether courts of appeal should adopt a more minimalist approach through a greater usage of joint judgments. ${ }^{13}$

I analyse joint judgment prevalence and desirability in the NSWCA, the New South Wales Court of Criminal Appeal ('NSWCCA') and the Federal Court of Australia - Full Court ('FCAFC'). By doing so, I aim to respond to President Beazley's 'dalliance on a curiosity' ${ }^{14}$ of whether the various mid-level courts of appeal are, like the HCA, trending toward a greater usage of joint judgments, and whether there is normative evidence to suggest that intermediate appellate courts should preference joint judgments over separate concurring reasons.

See, eg, Lynch, '2019 Statistics' (n 6) 1238, where unanimity in 2019 was comparatively 'very scarce' to prior years.

10 Lynch and Williams, '2018 Statistics' (n 8) 1454. See also Joe McIntyre and Jordan Tutton, 'Continuity or Change? Judicial Behaviour and Judgment Writing in the High Court of Australia 2000-2018' (Paper, 16 December 2019) 34-5, 41<https://ssrn.com/abstract=3676042>, where the authors observe a 'demonstrable shift in the decision-making patterns' of the French and Kiefel Courts to favour joint judgments.

${ }_{11} \quad$ Beazley (n 1) 79, where her Honour observed that HCA writing has shifted away from an era of ' 5 7 separate judgments' per matter to a 'minimalist, largely propositional style of reasons, often with a plurality judgment'.

12 Russell Smyth and Paresh Kumar Narayan, 'Hail to the Chief! Leadership and Structural Change in the Level of Consensus on the High Court of Australia' (2004) 1(2) Journal of Empirical Legal Studies 399,404 .

Beazley (n 1) 79.

14 Ibid. 
In this article, I first explore the 'small explosion in the literature'15 on joint judgments in the HCA and the conversely scant commentary on intermediate appellate courts. I then conduct an original empirical study of NSWCA, NSWCCA, and FCAFC judgment writing from 2009 to 2019 inclusive. In doing so, I address a deficiency in academic knowledge on the contemporary judgment writing practices of these courts. To inform later normative analysis, I provide detailed information to highlight trends and demonstrate varying or similar writing practices in these courts. I finally evaluate whether Chief Justice Kiefel's joint judgments as an 'institutional responsibility' ${ }^{16}$ proposition is similarly congruous with intermediate appellate court functions and current practice. To do so, I offer my own judgment on whether judges in courts such as the NSWCA, NSWCCA, and FCAFC should prefer joint judgments to separate concurring reasons.

\section{BACKGROUND}

In Australia, there is a general constitutional requirement for those exercising judicial power to enter reasons for judgment. ${ }^{17}$ Precisely how judicial officers express their reasons, however, is discretionary. In the case of agreement on a multi-member court, judges might choose to join in with similarly minded colleagues and draft a joint judgment. Joint judgments appear in two forms. The first is a unanimous joint judgment (or judgment of the Court) where all justices agree and subscribe their names to a single set of reasons. The second is a plurality judgment where some justices agree and place their names to a set of reasons. ${ }^{18}$ For example, in a three-member court a joint judgment may appear as:

Andrew Lynch, 'Keep Your Distance: Independence, Individualism and Decision-Making on MultiMember Courts' in Rebecca Ananian-Welsh and Jonathan Crowe (eds), Judicial Independence in Australia: Contemporary Challenges, Future Directions (The Federation Press, 2016) 156, 158 ('Keep Your Distance').

Kiefel, 'The Individual Judge' (n 2) 560.

See generally Luke Beck, 'The Constitutional Duty to Give Reasons for Judicial Decisions' (2017) 40(3) University of New South Wales Law Journal 923.

Plurality is a nebulous term. In the United States, a plurality is 'the existence of a majority agreement' on a 'result' without a majority agreement on the 'reasons' or 'underlying rationale that supports' the result: Ryan C Williams, 'Questioning Marks: Plurality Decisions and Precedential Constraint' (2017) 69(3) Stanford Law Review 795, 827. Australia 'has not adopted' the United States definition and instead 'has developed its own use': David Ash, 'The Vogue Word "Plurality") (Summer, 2018) Bar News: The Journal of the NSW Bar Association 56, 56. In Australia, a "'judgment of the plurality" " is when 'a number' of, but not all, justices agree and write together: Kiefel, 'Judicial Methods in the $21^{\text {st }}$ Century' (n 3) 6. For example, on a seven-member court, a jointly written set of reasons with two, three, four, five, or six justices' names placed on it is a plurality judgment, and in a three-member court, a jointly written set of reasons with two justices' names placed on it is a plurality judgment. Ash identified, at 62, two relevant HCA uses of the term: in Commissioner of Taxation v Jayasinghe (2017) 260 CLR 400 (five justices presiding) where Gageler J agreed with the 'orders proposed by the plurality' of Kiefel CJ, Keane, Gordon and Edelman JJ, and 
The Court (a unanimous joint judgment or a judgment of the Court) Reasons for judgment.

Or:

Judge A and Judge B ( a plurality judgment)

Reasons for judgment.

Judge C ( a separate concurring judgment)

I agree with the judgment of Judge A and Judge B.

Judges may also opt to write separate individual judgments, which appear as:

\section{Judge A}

Reasons for judgment.

\section{Judge $B$}

Reasons for judgment.

\section{Judge C}

Reasons for judgment.

As former President of the Supreme Court of the United Kingdom David Neuberger observed, the choice for a judge to write jointly or separately is far from clear:

There is much debate around the issue ... At one extreme is the [European Union], Luxembourg, Court civilian law model, where the court must produce a unanimous,

\footnotetext{
in Stuart v Kirkland-Veenstra (2009) 237 CLR 215 (six justices presiding) where French CJ agreed with 'the orders proposed in the plurality judgment of Gummow, Hayne and Heydon JJ'. In Australia, there can be more than one plurality judgment in a matter. See Darby $v$ R [2016] NSWCCA 164 where Rothman J, at [143], cited 'the plurality' of Gleeson CJ, Hayne and Callinan JJ and then at [144] cited 'the other plurality judgment' of McHugh, Gummow and Kirby JJ from MFA $v$ The Queen (2002) 213 CLR 606 (six justices presiding). Intermediate appellate courts have also adopted the term 'plurality judgment'. See Jamsek v ZG Operations Australia Pty Ltd [2020] FCAFC 119 where Anderson J, at [183], cited the 'plurality judgment' of North and Bromberg JJ in Fair Work Ombudsman v Quest South Perth Holdings Pty Ltd (2015) 228 FCR 346 (three justices presiding). Lower courts have applied the plurality judgments of intermediate appellate courts. See Dincel Construction System Pty Limited v AFS Systems Pty Ltd (No 2) [2017] FCA 791 where Nicholas J at [60] noted the 'plurality judgment' of Besanko, Foster, Nicholas and Yates JJ in the FCAFC in AstraZeneca $A B v$ Apotex Pty Ltd (2014) 226 FCR 324 (five justices presiding). See also Imagatec Pty Ltd $v$ GosleyFuller [2012] QDC 15 where Dorney DCJ at [25] applied the 'plurality judgment of Warnick and Boland JJ' in the Family Court of Australia - Full Court in Puddy \& Grossvard and Anor [2010] FLC 93-432 (three justices presiding).
} 
somewhat anonymous, judgment ... At the other extreme is the traditional UK House of Lords model ... with the multiple, idiosyncratic, judgments ... ${ }^{19}$

Underpinning the desirability of joint judgments is a broader schismatic question of judicial independence and collective responsibility. On the one hand, individualism would champion each judge's unique voice, and would offer scepticism over the anonymising and minimalist effects of joint judgments. Institutionalism, meanwhile, would prefer a unified court where possible. It would view joint judgments as preferable by instilling both authority to, and clarity within, a court's ratio decidendi, and criticise separate concurring judgments as 'unnecessary gloss'. ${ }^{20}$

Historical HCA practice reflects this dichotomy, fluctuating towards and away from joint judgments. However, contemporary HCA practice appears to have shifted towards consistent use of the style. What is much less clear is the extent to which Australian intermediate appellate courts draft, and broadly accept, joint judgments.

\section{A High Court of Australia}

There is conflicting literature on early HCA judgment writing practices. On the one hand, Bagaric and McConvill's empirical study found that, from 1954 to 2003, 'certainly the portion of separate majority decisions had not increased' over time, and that HCA judgments were 'not in 2003 more fragmented' by separate concurring opinion 'than in other years' ${ }^{21}$ The authors answered their hypothesis that the HCA had an 'increasing tendency to deliver multiple majority judgments' ${ }^{22}$ in the negative, suggesting that joint judgments have been consistently well-utilised in HCA practice. However, as the authors acknowledged, their results are 'of course not conclusive'23 as their methodology examined HCA judgments in 'only [the] four years'24 of 1954, 1978, 1993, and 2003. ${ }^{25}$ If the authors completed a population study of all judgments in between two dates, or gathered an appropriately larger sample while using systematic or stratified statistical techniques, their trend identification could be more definitive.

Baron David Neuberger, 'Sausages and the Judicial Process: The Limits of Transparency' (Speech, Annual Conference of the Supreme Court of New South Wales, 1 August 2014) [31] $<$ https://www.supremecourt.uk/docs/speech-140801.pdf> ('Sausages and the Judicial Process'). Coper, 'Concurring Judgments' (n 4) 129. Mirko Bagaric and James McConvill, 'The High Court and the Utility of Multiple Judgments' (2005) 1(1) High Court Quarterly Review 13, 28.

Ibid 13. Ibid 28 .

Ibid. Ibid $14-15$ 
Other literature indicates that HCA use of joint judgments ebbed and waned ${ }^{26}$ and widely fluctuated ${ }^{27}$ for most of the $20^{\text {th }}$ century. In their empirical study of HCA judgment writing practices, Groves and Smyth observed 'historical highs' in the HCA's joint judgment use 'in the early 1920s, in the 1950s, and 1990s', and 'historical lows in the late 1930 s to mid-1940s and in the 1970s' ${ }^{28}$ They observed that the extent to which the HCA produced joint judgments is somewhat correlated to a Chief Justice's preference for institutionalism, and also a Chief Justice's ability 'to build a more collegial atmosphere'. ${ }^{29}$ Consistently with Groves and Smyth's study, Sir Anthony Mason observed that joint judgments were prevalent under Chief Justices Knox and Dixon, and less prevalent under Chief Justices Griffith, Isaacs, Duffy, Latham, Barwick, and Gibbs. ${ }^{30}$

Literature indicates that the Mason Court produced a comparatively higher proportion of joint judgments than earlier courts. ${ }^{31}$ With this in mind, it is unsurprising that Sir Anthony himself expressed an institutionalist view, stating that 'it is the Court, rather than the individual Justices, that decides the case and declares the law'. ${ }^{2}$ He viewed it as the 'strong responsibility' of the Chief Justice and all puisne justices to 'explore the possibility of delivering' a joint judgment.33 While 'the move towards joint judgments gained some momentum' under Mason's leadership, it was 'not to the extent that we had hoped', with joint judgments remaining as an underutilised tool in his Court's judicial inventory. ${ }^{34}$ Indeed, President Beazley characterises the Mason era as a time of ' $5-7$ separate judgments of 100 plus pages'. ${ }^{35}$ Sir Anthony attributed the persistent judgment fragmentation in his Court to, inter alia, the fundamental 'right of a Justice to deliver his own judgment in order to do justice to his own independent and impartial opinion'. ${ }^{6}$ He also attributed his Court's frequently separated judgments to 'deep-seated divisions within the Court' and the absence of a collective desire to compromise, and in the 'lack of consensus as to the role of the

Partovi et al (n 4) 703. See also Graeme Orr, 'Verbosity and Richness: Current Trends in the Craft of the High Court' (1998) 6(3) Torts Law Journal 291, 292.

Matthew Groves and Russell Smyth, 'A Century of Judicial Style: Changing Patterns in Judgment Writing on the High Court 1903-2001' (2004) 32(2) Federal Law Review 255, 266-7.

Ibid.

Ibid 268.

Sir Anthony Mason, 'The High Court of Australia: Reflections on Judges and Judgments' (2013) 16 Southern Cross University Law Review 3, 3-9 ('Reflections'). On Griffith CJ, cf Smyth and Narayan (n 12) 404 where ' $[u]$ nder the leadership of the High Court's first Chief Justice, Griffith (1903-1919), between 1903 and 1906, the High Court experimented with a single opinion of the Court'. Partovi et al (n 4) 671.

Sir Anthony Mason, 'Chief Justice, Role of' in Tony Blackshield, Michael Coper and George Williams (eds), The Oxford Companion to the High Court of Australia (Oxford University Press, 2001) 90, 91. Ibid.

Mason, 'Reflections' (n 30) 9.

Beazley (n 1) 79.

Mason, 'Reflections' (n 30) 10. 
Court'. ${ }^{37}$ His reflection suggests that joint reasons require active judicial collaboration, and that such judgments are neither precipitous nor unexpected.

Empirical evidence indicates that Justices on the Brennan Court had a somewhat lower tendency to join in. ${ }^{38}$ The Gleeson Court, meanwhile, 'curiously manage[d] to combine strong levels of agreement with the presence of significant individualism from several of its members' ${ }^{39}$ Nevertheless, the Gleeson Court still experienced some 'remarkable' division in the writing of its judgments, 40 especially in its early years. ${ }^{41}$ As a pertinent example, Justice Michael Kirby, a 'determined individualist' who presided on both the Brennan and Gleeson Courts, ${ }^{42}$ pushed against joint judgments on the grounds that they can cloud judicial function, stating that 'honesty and transparency encourage and reinforce the proper discharge of the judicial function. Where necessary this requires the provision of separate reasons' ${ }^{4} 3$

Similarly, Justice Dyson Heydon, who sat on the Gleeson Court, comprehensively rejected joint judgments and any collaboration, stating that the practice of joining in completely undermines judicial independence. 44 Despite routinely participating in joint judgments early in his HCA appointment, 45 Justice Heydon later took the view that to join in reasons that were authored primarily by another suggested 'that the judicial process has been skimped or nonchalant or "perfunctory", , and that joining in demonstrates 'judicial herd behaviour'. ${ }^{46}$ Justice Heydon, quoting Roderick Munday, submitted that separate reasons instil 'humanity' into the court's overall judgment, and provide necessary evidence 'that each member of the court has fully met [his or her judicial] responsibilities and given the arguments presented scrupulous attention' ${ }^{47}$

The contemporary HCA offers a dramatically stronger acceptance of joint judgments. ${ }^{48}$ In 2014, Justice Susan Kiefel attempted to rebut Heydon by emphasising that joint judgments assist in achieving 'clarity, certainty and

Ibid.

Andrew Lynch, 'Does the High Court Disagree More Often in Constitutional Cases? A Statistical Study of Judgment Delivery 1981-2003' (2005) 33(3) Federal Law Review 485, 508-10.

Ibid 513.

Andrew Lynch and George Williams, 'The High Court on Constitutional Law: The 2007 Statistics' (2008) 31(1) University of New South Wales Law Journal 238, 240.

Beazley (n 1) 79.

Andrew Lynch, 'The Gleeson Court on Constitutional Law: An Empirical Analysis of Its First Five Years' (2003) 26(1) University of New South Wales Law Journal 32, 59. See also Orr (n 26) 299-301.

Justice Michael Kirby, 'Judicial Dissent: Common Law and Civil Law Traditions' (Speech, Law Quarterly Review, 2007) 39-40 (citations omitted) <https://cdn.hcourt.gov.au/assets/ publications/speeches/former-justices/kirbyj/kirbyj_o6.pdf $>$.

Justice Dyson Heydon, 'Threats to Judicial Independence: The Enemy Within' (2013) 129 (April) Law Quarterly Review 205, 221-2.

Lynch, 'Keep Your Distance' (n 15) 161.

Heydon (n 44) 215, 217 (citations omitted).

Ibid 207, quoting Roderick Munday, 'Judicial Configurations: Permutations of the Court and Properties of Judgment' (2002) 61(3) Cambridge Law Journal 612, 634.

Kiefel, 'The Individual Judge' (n 2) 557; Kiefel, 'Judicial Methods in the $21^{\text {st }}$ Century' (n 3) 11. 
timeliness' 49 and a 'proper understanding of what the court is saying'. ${ }^{50}$ Justice Kiefel encouraged the 'discipline' in tempering individualism and working collegially toward an 'authoritative voice' of the court, especially in matters of 'considerable controversy'. ${ }^{51}$ Interestingly, Justice Kiefel stated that modern HCA practice is for a single judge to write the leading judgment, to which other justices then join should they concur. ${ }^{52}$ The general lack of a substantively collaborative writing effort could generate some scepticism about whether joint judgments crafted under Justice Kiefel's method are actually reflective of each individual judge's true views and understanding, as a 'joint judgment does not necessarily imply joint authorship'. ${ }^{53}$

Justice Patrick Keane and Justice Virginia Bell agree with Justice Kiefel's reasons for joint judgments. Justice Keane reminded his colleagues at a judicial colloquium that ' $[\mathrm{t}] \mathrm{he}$ administration of justice is not the work of individual judges ... [but] of an institution, and we have responsibilities for that institution'. ${ }^{54}$ He noted that the HCA's trend towards joint judgments 'is not a bad thing', as joined reasons are 'inherently more authoritative' and better 'fulfil [the court's] duty to the development of the law, and their duty to society'. ${ }^{55}$ Justice Bell described joint judgments as a 'public service' as they assist legal practitioners, law students, and lower courts in identifying with confidence what the law is. ${ }^{56}$ Her statements that 'judges have an institutional responsibility with respect to judgment writing that outweighs self-expression' and '[i]f the price of certainty and clarity is the loss of the individual judge's "voice", I suspect that few outside the Academy would count that as a bad thing' ${ }^{57}$ strongly demonstrate the apparent pendulum shift towards joint judgments and collectivism in the Kiefel Court. Described as a 'troika', ${ }^{8}$ Chief Justice Kiefel, Justice Bell and Justice Keane adopt a true institutionalist mindset, viewing judgments as a product of the court rather than of individual judges.

While the Kiefel Court has normalised joint judgments, Chief Justice Kiefel prudently observes that '[o]ne cannot say that this method is here to stay' and

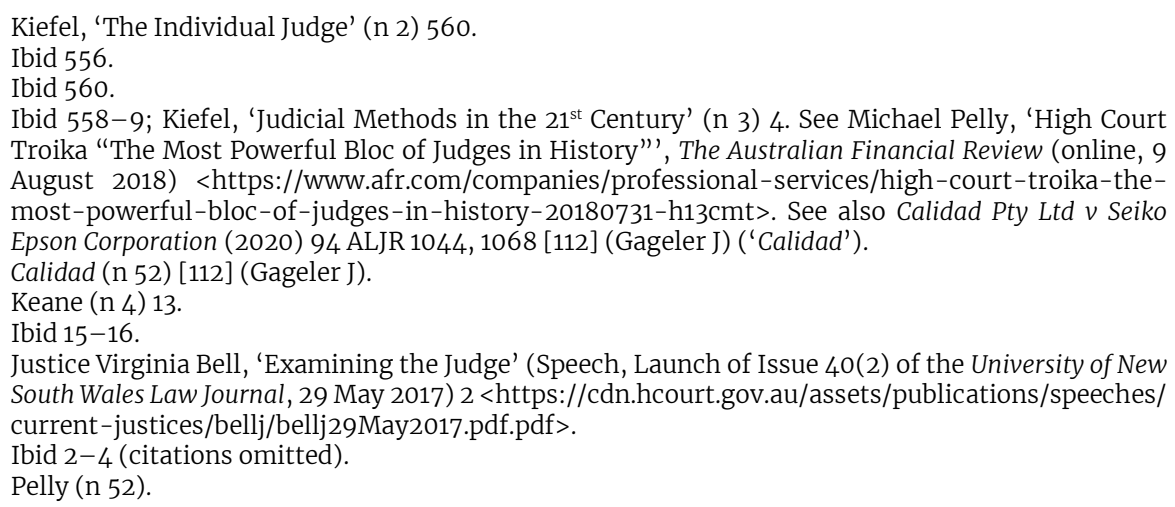
Troika "The Most Powerful Bloc of Judges in History"', The Australian Financial Review (online, 9 August 2018) <https://www.afr.com/companies/professional-services/high-court-troika-themost-powerful-bloc-of-judges-in-history-20180731-h13cmt>. See also Calidad Pty Ltd v Seiko Epson Corporation (2020) 94 ALJR 1044, 1068 [112] (Gageler J) ('Calidad'). South Wales Law Journal, 29 May 2017) 2 <https://cdn.hcourt.gov.au/assets/publications/speeches/ current-justices/bellj/bellj29May2017.pdf.pdf>. 
that much depends on the 'continued acceptance' of joining in. ${ }^{59}$ Indeed, the costs of reduced opinion diversity and pursuing '[p]roductivity over prose' ${ }^{60}$ include a greater tendency for 'very dry writing' and minimalist reasoning in order to reach compromise and consensus. ${ }^{61}$ With the departure of Justice Bell, a key proponent of joint judgments, and also Justice Geoffrey Nettle, the broad acceptance of joint judgments in the HCA was set to change if individualist judges were appointed. This is especially so with Justice Keane set to depart the HCA in 2022. Consequently, with the appointments to the HCA of former Federal Court Justice Jacqueline Gleeson and Justice Simon Steward, it is timely to ascertain the institutional practices of intermediate appellate courts such as the FCAFC. If judges appearing in the FCAFC consistently express their reasons through joint judgment, it seems likely that those judges would continue to operate with an institutionalist perspective if appointed to the HCA. If this is so, Chief Justice Kiefel's wishes for continued acceptance of joint judgments will be more likely realised with the appointment of Justices Gleeson and Steward.

\section{B Intermediate Appellate Courts}

One empirical study indirectly discussing joint judgment prevalence in Australian intermediate appellate courts was a 100-year review of the Supreme Court of Victoria's ('VSC') citation practices. ${ }^{62}$ The study found that 18.1 per cent of judgments in the VSC were joint judgments in 1975, but in 2005 the joint judgment proportion reduced to 5.7 per cent, indicating an increased preference for individualised reasons over time. ${ }^{63}$ The authors suggest that other intermediate appellate courts would have similar judgment writing practices to the VSC because they all 'share many of the same characteristics' and fundamental functions. ${ }^{64}$ The study ultimately provides some limited evidence to suggest that Victoria's superior court had a historically individualist approach to judgment writing.

Providing a more recent contrast to these empirical findings, Justice Robert Redlich states that the Victorian Court of Appeal ('VCA') prefers joint judgments. ${ }^{65}$ He identifies that the VCA's contemporary practice of using joint judgments is

Kiefel, 'Judicial Methods in the 21 $1^{\text {st }}$ Century' (n 3) 11.

Katie Walsh, 'Productivity Over Prose for High Court in $21^{\text {st }}$ Century: Chief Justice Susan Kiefel', The Australian Financial Review (online, 16 March 2017) <https://www.afr.com/politics/productivityover-prose-for-high-court-in-21st-century-chief-justice-susan-kiefel-20170315-guyz3m>.

Pelly (n 52). See also Beazley (n 1) 79.

Dietrich Fausten, Ingrid Nielsen and Russell Smyth, 'A Century of Citation Practice on the Supreme Court of Victoria' (2007) 31(3) Melbourne University Law Review 733.

Ibid 745 .

Ibid 737 .

Justice Robert Redlich, ' $20^{\text {th }}$ Anniversary of the Court of Appeal' (Speech, Court of Appeal of the Supreme Court of Victoria, 20 August 2015) $2-3$ <https://www.supremecourt.vic.gov.au/sites/ default/files/assets/2017/09/c1/obcfb7eb7/coa\%2B20th\%2Banniversary\%2Bspeech.pdf>. 
indicative of a 'strong collegiate spirit' within the court and, quoting Sir Raymond Evershed, demonstrates 'combined judicial operation' where VCA justices 'work truly together' ${ }^{66}$ Justice Redlich submits that joint judgments 'generally enhance' the overall quality of the VCA's reasons and enable the court to provide better guidance with 'greater certainty and consistency' ${ }^{67}$ His Honour draws on anecdotal evidence, which indicates a significant shift in Victorian appellate practice towards institutionalism expressed through greater joint judgment use. The degree, intensity, and general desirability of this shift, though, remains unclear.

The reflections of senior members of the NSW judiciary suggest that NSW courts' current approaches to judgment writing differs from Justice Redlich's account of Victorian practice in that joint judgments are not widely prevalent in the NSW appellate sphere. Sir Anthony Mason, for example, observed that NSWCA practice, when he was a Judge of Appeal (1969 to 1972), was to 'deliver separate individual judgments' ${ }^{68}$ President Beazley believes that current NSWCA and other intermediate appellate court practice is much less 'propositional' or minimalist when compared to HCA writing. ${ }^{69}$ NSW Chief Justice Thomas Bathurst has stated that judgment '[c]larity is undoubtedly greatly assisted by brevity ... but, like all virtues, [brevity] should not be taken to excess'.$^{70}$ His Honour makes no direct argument for joint judgments, but does indirectly point to their potential utility, stating that NSW courts must push against 'over-complication'71 and 'inaccessible' judgments that 'lack clarity'..$^{72}$

Meanwhile, extra-judicial writing points to some joint judgment use in the Federal Court. Justice Debbie Mortimer, a current Federal Court judge, argued that '[s]eparate appellate judgments can invite a lack of clarity', while joint judgments, in 'putting aside judicial ego', enhance judgment '[c]larity, accessibility and certainty'. ${ }^{73}$ Strikingly, her Honour submits that long and complex reasons and multiple judgments 'obscure the exercise of judicial power, rather than reveal it'. ${ }^{74}$ Justice Peter Heerey, using simple cost-benefit analysis, argues that the benefits of joint judgments in speeding up judicial deliberation far

66 Ibid 3.

Ibid.

Mason, 'Reflections' (n 30) 7.

Beazley (n 1) 82.

Chief Justice Thomas Bathurst, 'Writing Judgments with the Parties in Mind' (Keynote Address, National Judicial College of Australia 'Writing Better Judgments Program', 3 April 2017) [31]. <https://www.supremecourt.justice.nsw.gov.au/Documents/Publications/Speeches/2017\%20Spe eches/Bathurst\%20CJ/Bathurst_20170403.pdf>.

Ibid [28].

Ibid [26].

Justice Debbie Mortimer, 'Some Thoughts on Writing Judgments In, and for, Contemporary Australia' (2018) 42(1) Melbourne University Law Review 274, 290.

$74 \quad$ Ibid 296. 
outweigh any perceivable cost. ${ }^{75}$ Justice Heerey believes that the Federal Court should, and generally does, eschew multiple separate judgments because they severely reduce clarity in developing the law, delay cases, and waste resources..$^{66}$ Nevertheless, in contrast, Justice Katrina Banks-Smith argues that judges are 'fully entitled to add their own colour'. This proposition resonates with President Beazley's comments, which question the minimalist features of joint judgments, and could indicate some continued use of additional separate reasoning in the Federal Court.77

Overshadowing these judicial comments is an optional 2017 'Judgment Writing Protocol for Intermediate Appellate Court Judges'. ${ }^{78}$ While the Protocol requests that judges reject ' $[\mathrm{u}] \mathrm{nnnecessarily} \mathrm{long'} \mathrm{judgments,}{ }^{79}$ the Protocol states that any rule requiring courts to preference joint judgments is 'not suitable'.$^{80}$ It nevertheless encourages the '[j]oint preparation of opinions' in 'difficult or contentious appeals, where the court has conflicting precedents, and where the reasons are clearly divisible' ${ }^{81}$ Importantly, this Protocol indicates that there might not be uniformity or even similarity in how Commonwealth, state, and territory intermediate courts of appeal approach the question of joint judgment desirability.

A shortage of empirical and, indeed, anecdotal evidence on intermediate appellate court writing practice provides a fragmented and limited picture of joint judgment prevalence and desirability in these courts. While the HCA has shifted to a practice of joined expression where possible, reflecting the emphasis under Chief Justices French and Kiefel for a more institutional approach, it is largely unclear whether intermediate appellate courts adopt a broadly similar or contrary approach, and whether this differs across jurisdictional setting.

\section{Profile of Judgment Writing Practices}

To address the deficit of empirical information on intermediate appellate court judgment writing practices, I completed a statistical study involving all

Peter Heerey, 'The Judicial Herd: Seduced by Suave Glittering Phrases?' (2013) 87(7) Australian Law Journal 460 .

Ibid 463.

Justice Katrina Banks-Smith, 'More Than Just Precedent: Perspectives on Judgment Writing' (Speech, The Honourable David Malcolm Annual Memorial Lecture, Notre Dame University School of Law, 10 October 2019) [41] <https://www.fedcourt.gov.au/digital-law-library/judgesspeeches/justice-banks-smith/banks-smith-j-20191009>.

'Judgment Writing Protocol for Intermediate Appellate Court Judges', National Judicial College of Australia, (Web Page) <https://njca.com.au/wp-content/uploads/2017/12/Appeal-CourtJudgment-Writing-Protocol.pdf $>$.

Ibid 1 [7].

Ibid 4 [21].

Ibid 4 [21]. 
judgments entered by the NSWCA, NSWCCA, and FCAFC in each calendar year from 2009 to 2019 inclusive.

Empirically ascertaining the historical decision-making practices of courts provides an informative context for, as an example, normative analysis of joint judgments. By profiling how multi-member courts enter reasons for judgment over time, the Academy may better understand the tendencies and movements in how judges approach their principal craft of judgment writing. ${ }^{82}$

A total of 10,144 judgments were delivered between the three intermediate appellate courts from 2009 to 2019: 4,455 from the NSWCA, 3,533 from the NSWCCA, and 2,156 from the FCAFC. For NSW courts, judgments were collected from NSW Caselaw, ${ }^{83}$ while FCAFC judgments were sourced from the Federal Court website's 'Judgments Search' function in its Digital Law Library. ${ }^{84}$

In line with best empirical practice and to ensure that 'the reader [can] assess for himself the accuracy and value of the information conveyed', 85 a live hyperlink to the Excel spreadsheets containing the raw data for each of the 10,144 judgments screened is available in this article's Appendix. A detailed guide on how to read the raw data is contained in the first tab of each spreadsheet.

\section{A Empirical Methodology}

The calendar years 2009 to 2019 inclusive were chosen to approximately coincide with the French and Kiefel Courts. Given the resources required to manually discern and process every case number for each year, I decided to focus on three intermediate appellate courts: the NSWCA, NSWCCA, and FCAFC. NSW was selected as a geographic jurisdiction as this study is a response to former NSWCA President Beazley's article. The FCAFC was chosen to enable some comparative analysis of a court with co-ordinate jurisdiction and to provide a more comprehensive picture of the varying or similar practices and approaches used by intermediate appellate courts.

The study's first step was to distinguish all medium neutral citation case numbers for one calendar year into an 'eligible population' and an 'excluded population'.

As this study is interested only in judgment writing practices in multimember matters, and because joint judgments can only occur where two or more judges preside, case numbers where only a single judge presided were placed in

82 See, eg, Andrew Lynch, 'Dissent: Towards a Methodology for Measuring Judicial Disagreement in the High Court of Australia' (2002) 24(4) Sydney Law Review 470, 472-3.

83 'Advanced Search', New South Wales Caselaw (Web Page, 8 September 2021) <https://www.caselaw. nsw.gov.au/search/advanced>.

84 'Digital Law Library: Judgments Search', Federal Court of Australia (Web Page, 2021) <https://www.fedcourt.gov.au/digital-law-library/judgments/search>.

85 Louis Henkin, 'The Supreme Court: 1967 Term' (1968) 82(1) Harvard Law Review 63, 302. 
the 'excluded population'. Case numbers where two or more judges entered reasons were placed in the 'eligible population', except in two instances.

The first instance was when the case number was not in use at the time of examination. For example, the case number '[2019] NSWCCA 34' was not used by that Court, and no reasons were entered under that case number. Consequently, it was placed in the 'excluded population'.

The second instance was when the case number was restricted at the time of examination. For example, the case number '[2019] NSWCCA 6' was restricted by that court, and the judgment text is completely redacted. Because the writing practices used within that judgment cannot be ascertained, it was placed in the 'excluded population'.

The FCAFC had no restricted cases listed from 2009 to 2019, and the NSWCA had only three restricted cases in 2016 (0.91 per cent of total cases for that year) and none in other years. Restricted cases in the NSWCCA ranged from 0 in 2010 to a high of 13 cases in 2019 ( 4.08 per cent of total cases for that year).

The study's second step was to capture information on how judges in 'eligible population' case numbers for the calendar year entered their reasons. Data on the proportion of the reasons that were in the form of the following categories was manually recorded:

- Joint judgment (two or more judges placing their names, equally and jointly, to a set of reasons. This includes any joint reasons in dissent, or are the leading judgment and provide the orders of the court, or that are in concurrence through the form of 'we agree' or through additional or different reasons. It also includes unanimous reasons if all judges ascribe their name to the reasons equally).

- Single leading judgment (one judge's set of reasons that contain the orders that a majority of other judges concur with separately. If a joint judgment contained the orders of the court, it would not be placed into this category. Rather, it would be categorised as a joint judgment).

- Concurrence with the leading judgment with a separate 'I agree' statement, or words to that effect, including brief comments or observations that are non-substantive.

- $\quad$ Concurrence with the leading judgment, but with additional or different reasons (this category captures any separate concurring reasons that are substantive).

- $\quad$ Standalone dissent (individual reasons that provide different orders to the leading judgment).

Differentiating between a concurrence with a separate 'I agree' statement or words to that effect, and a concurrence but with additional or different reasons, could from time-to-time involve discretion. For example, a set of reasons that 
states agreement with the leading judge but then offers a brief comment on how interesting the matter was would be categorised as a concurrence with the leading judgment with a separate 'I agree' statement or words to that effect, as the very short remark on the interesting nature of the case is non-substantive reasoning.

To illustrate the data categorisation process, the case number '[2019] NSWCA 243' had five judges presiding. Bell P provided an individual judgment that contained the Court's orders, so his Honour's judgment was categorised as the 'single leading judgment'. Meagher and Payne JJ entered into a joint judgment, in which they agreed with Bell P's orders and his Honour's reasons, but added additional remarks. Meagher and Payne JJ's judgment was categorised as a 'joint judgment'. Macfarlan J separately wrote the following reasons: 'I agree with Bell P'. His judgment was categorised as a concurrence with the leading judgment with 'I agree'. Finally, White J gave a separate individual bare concurrence with Bell P. White J's judgment was categorised, like that of Macfarlan J, as a concurrence with the leading judgment with 'I agree'.

Each case number could have a different number of judges presiding. Thus, case numbers required normalisation. To normalise each case, I assumed each case number had a numerical value of 1 . I then ascribed a decimal value for each judge in that case proportionate to the total number of judges presiding. When added, these decimal values would equal 1. I observed how each judge in that case number entered their reasons according to this study's identified categories, and then captured this information in proportionate decimal form.

For example, the case number '[2019] NSWCCA 1' had three judges presiding. One judge entered a single leading judgment, one judge concurred with that leading judgment in the form of 'I agree', and one judge concurred with the leading judgment but with additional or different reasons. Consequently, 0.33 (ie, $1 / 3$ ) of the judges in this case number were recorded as writing a single leading judgment, 0.33 was recorded under concurrence with 'I agree', and 0.33 was recorded under concurrence with additional or different reasons.

As another example, the case number '[2018] NSWCCA 70' had five judges presiding. One judge entered a leading judgment, and four judges entered separate concurring judgments with additional or different reasons. Consequently, 0.2 (ie, 1/5) of the judges in this case number were recorded as writing a single leading judgment, and 0.8 (ie, 4/5) was recorded under concurrence with additional or different reasons.

After initial collection, I validated the data's accuracy and reliability through random case number checks. Any residual categorisation errors, if they appear, are my responsibility.

The study's third step, once all case numbers and their proportions for a calendar year were captured, was to sum all the values for each category, divide the result over the eligible population, multiply the figure by 100 and round it to two decimal places to obtain a 'proportion percentage' for that category in that year. 
For example, for the year 2019 in the NSWCCA, the eligible population was 306 judgments. The proportion of reasons that appeared in the form of joint judgment was 29.34. Thus: $(29.34 / 306) * 100=9.59$ per cent. This means that 9.59 per cent of the NSWCCA's reasons in matters involving multiple judges were entered in the form of joint judgment in 2019.

The study repeated steps one to three for each year from 2009 to 2019 inclusive for each of the NSWCA, NSWCCA, and FCAFC.

The study's fourth step was to create visual material to display the 'proportion percentage' movements through bar charts of the joint judgment, concurrence with 'I agree', and concurrence with additional or different reasons categories. Because the data collected is a time series, an Excel generated 10 -year moving average line is plotted on each bar chart to smooth out the jagged effect of short-term fluctuations and facilitate long-term trend identification. ${ }^{86}$

I do not provide information on single leading judgments. Leading judgment data is only recorded in the spreadsheets for data collection completeness and to facilitate information capture on joint judgments and separate reasons. Standalone dissent data is also not displayed. Since any dissents in joint judgment are included in the 'joint judgment' category, the standalone dissent category does not provide a complete picture of dissent movement over time. Like leading judgments, standalone dissent proportions were captured in the spreadsheets to ensure data collection completeness.

Two confounding variables potentially limit the utility of this study's results. The first confounder is the type of law examined in each case. Some types of law may facilitate more joint judgment than other types of laws due to factors such as difficulty or the need for clarity, and certain years might have higher rates of matters concerning that type of law than other years, leading to an exaggerated increase in joint judgments. As Justice Kiefel observed, for example, from her experience judges in constitutional law cases 'write separately' more often due to the 'novel questions' presented. ${ }^{87}$ The second confounder is the individual judges presiding in each case. Some judges, for example, may have a disproportionately higher tendency to enter into joint judgment than other judges. If certain joint judgment preferencing judges appear more regularly than non-joint judgment preferencing judges in a particular year, then joint judgment usage could increase for that year. The same logic applies vice versa: if individualistic judges appear more frequently in one year, then joint judgment usage could decrease for that year. Further, as Justice Kiefel identified, the specific judicial composition for each case may also affect potential for joint judgment: if, for example, the judges listed in a certain case all enjoy good working relationships or are 'of a similar cast of

86 See Stephanie Glen, 'Moving Average: What It Is and How to Calculate It', Statistics How To (Web Page, 2021) <https://www.statisticshowto.com/probability-and-statistics/statistics-definitions/ moving-average/ $>$.

$87 \quad$ Kiefel, 'The Individual Judge' (n 2) 559. 
mind', they 'are simply more likely to agree' ${ }^{88}$ Analysing the impact, if any, of these confounding variables is outside the scope of this study. However, raw data on both confounding variables for every case number is captured in the Excel spreadsheets found at this article's Appendix (the exception being the law type variable in the NSWCCA, as the law type examined in every NSWCCA case is criminal law and procedure).

\section{$1 \quad$ NSWCA}

\section{B Results}

(a) Joint judgments

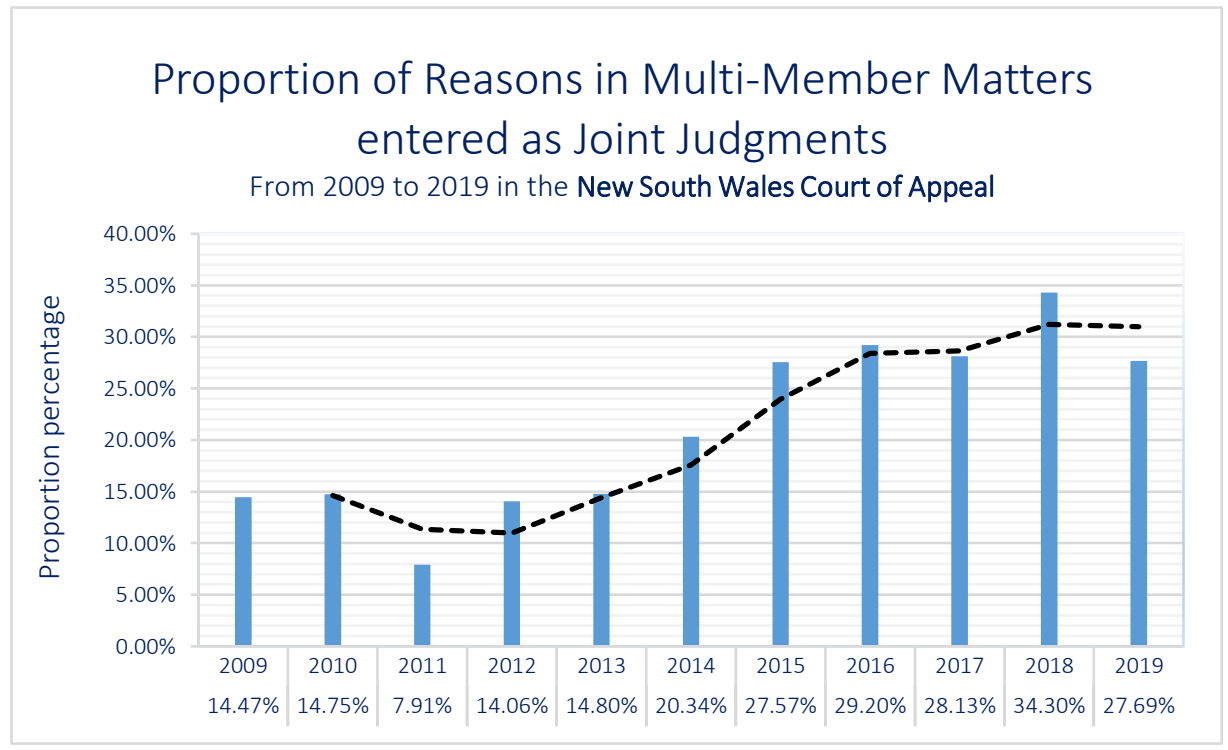

The proportion of NSWCA reasons entered as joint judgments more than quadrupled from a trough of 7.91 per cent in 2011 to a peak of 34.30 per cent in 2018. 
(b) Concurrence with 'I agree'

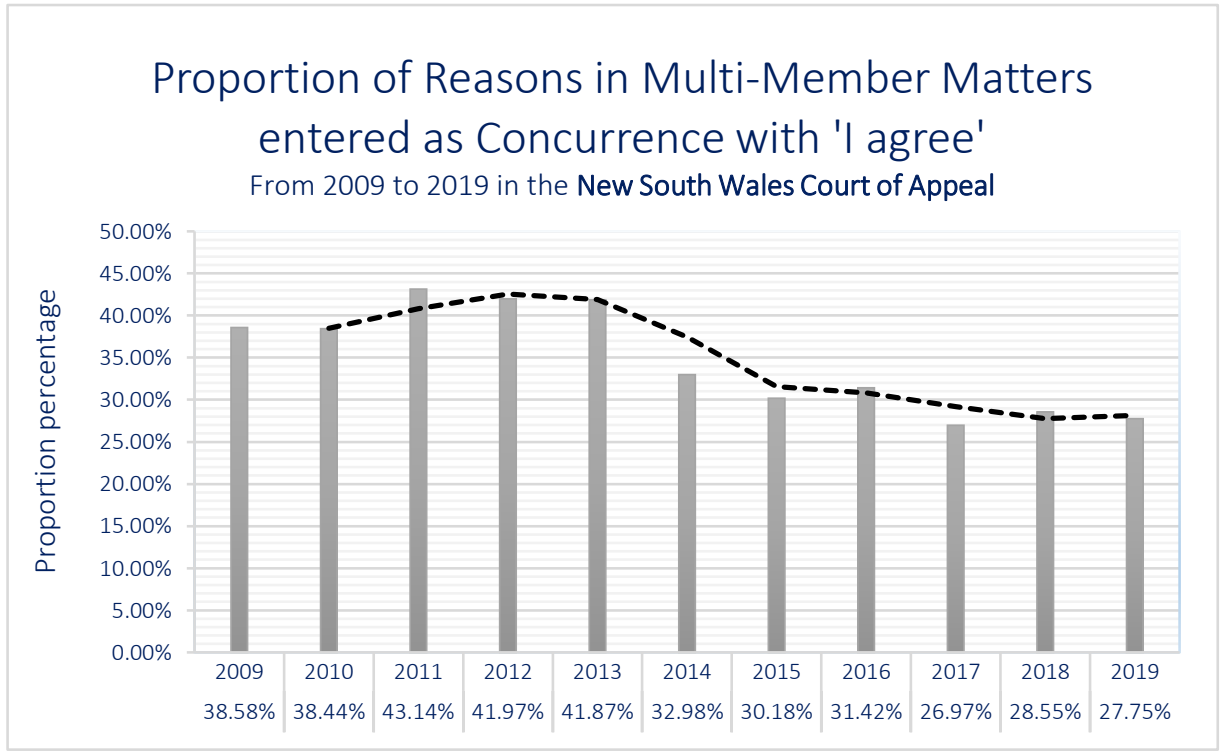

The proportion of NSWCA reasons entered as a concurrence with the leading judgment in the form of 'I agree' or words to that effect reduced significantly from a peak of 43.14 per cent in 2011 to a trough of 26.97 per cent in 2017.

(c) Concurrence with additional or different reasons

Proportion of Reasons in Multi-Member Matters entered as Concurrence with Additional or Different Reasons

From 2009 to 2019 in the New South Wales Court of Appeal

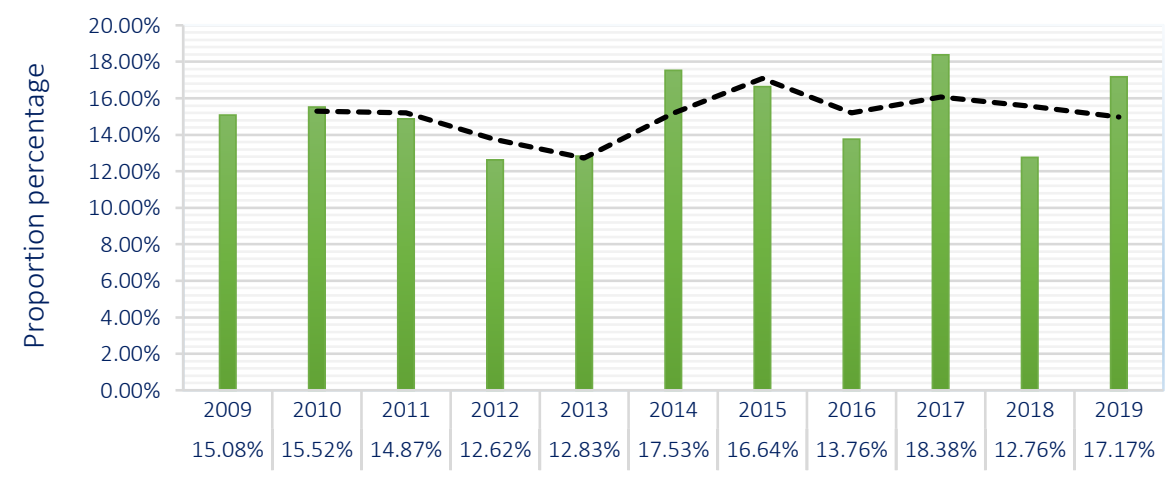


The proportion of NSWCA reasons entered as concurrence with the leading judgment with additional or different reasons has remained relatively static, offering slight growth over 11 years from 15.08 per cent in 2009 to 17.17 per cent in 2019.

\section{(d) NSWCA: Discussion}

There is a very strong upward trend in the usage of joint judgments in the NSWCA. In only nine years, joint judgments in the NSWCA have rapidly transitioned from a rarer form of expression to a commonplace means by which members of the Court provide their reasons.

As the use of joint judgments rises, entering reasons in the plain form of ' $\mathrm{I}$ agree' has commensurately dropped. This demonstrates that the practice of bare individual concurrence is becoming less prevalent in the NSWCA and suggests that judges who agree with the leading judgment are now more likely to join into that judgment rather than simply agree with it through a separate entry. What has not decreased with the rise of joint judgments, however, is the NSWCA's expression of concurrence with additional or different reasons. Instead, concurrence with substantive reasons has grown, albeit only slightly, over the 11 years examined. This indicates that an increase in joint judgments has seemingly no effect on reducing multiple substantive judgments.

Nevertheless, NSWCA judges appear to face a transitional moment in the norms of their judgment writing practices. Joint judgments have become so prevalent that they now complement the historically dominant practice of concurrence with a single leading judgment through an 'I agree' entry. However, if NSWCA judges increasingly accept joint judgments as desirable, and the form continues to grow in use as rapidly as it has in the past nine years, joint judgments will surpass bare concurrence proportions and become the primary way of entering reasons. 


\section{NSWCCA}

(a) Joint judgments

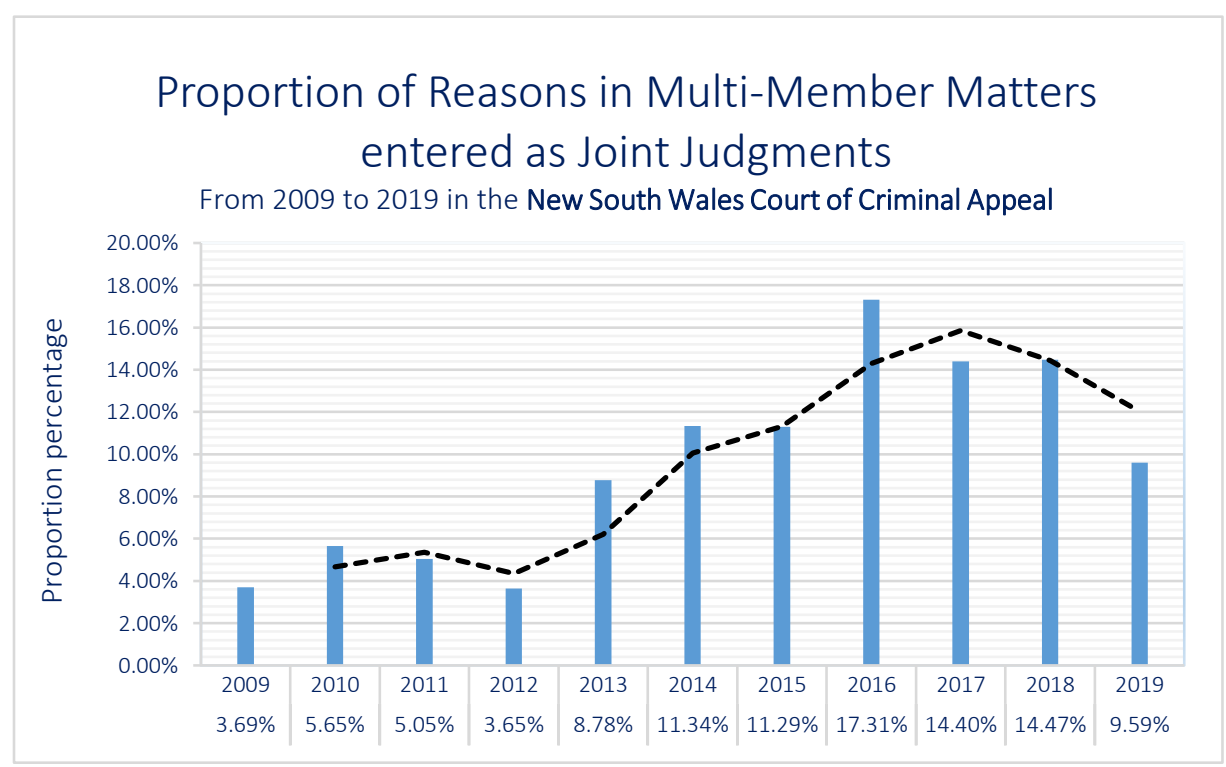

The proportion of NSWCCA reasons entered as joint judgments more than quadrupled from a trough of 3.65 per cent in 2012 to a peak of 17.31 per cent in 2016.

\section{(b) Concurrence with 'I agree'}

\section{Proportion of Reasons in Multi-Member Matters entered as Concurrence with 'I agree' From 2009 to 2019 in the New South Wales Court of Criminal Appeal}

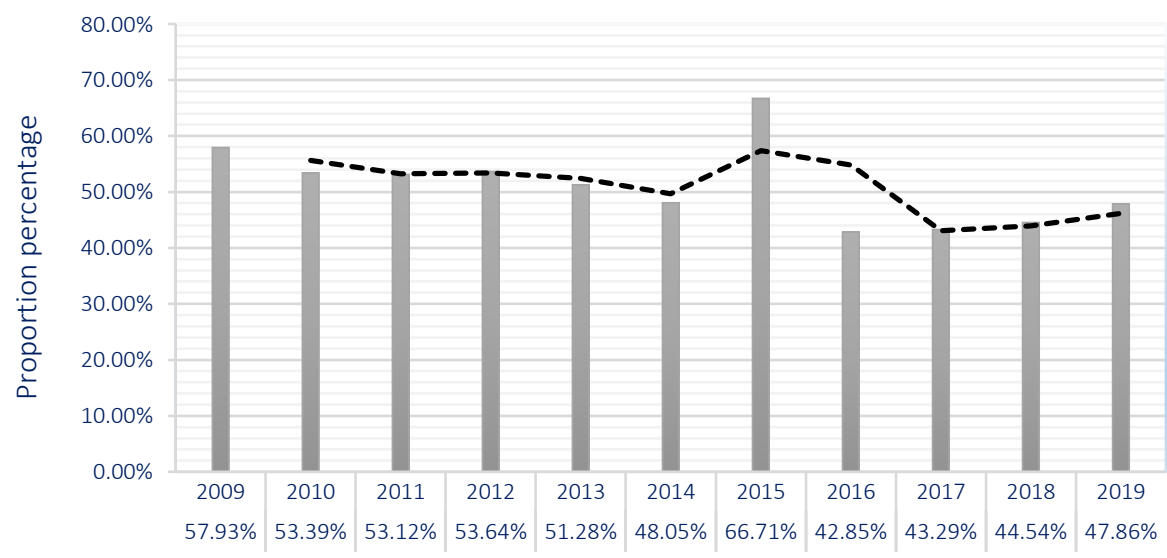


The proportion of NSWCCA reasons entered as a concurrence in the simple form of 'I agree' reduced from a high of 57.93 per cent in 2009 to a low of 42.85 per cent in 2016 (excluding the 66.71 per cent outlier in 2015).

\section{(c) Concurrence with additional or different reasons}

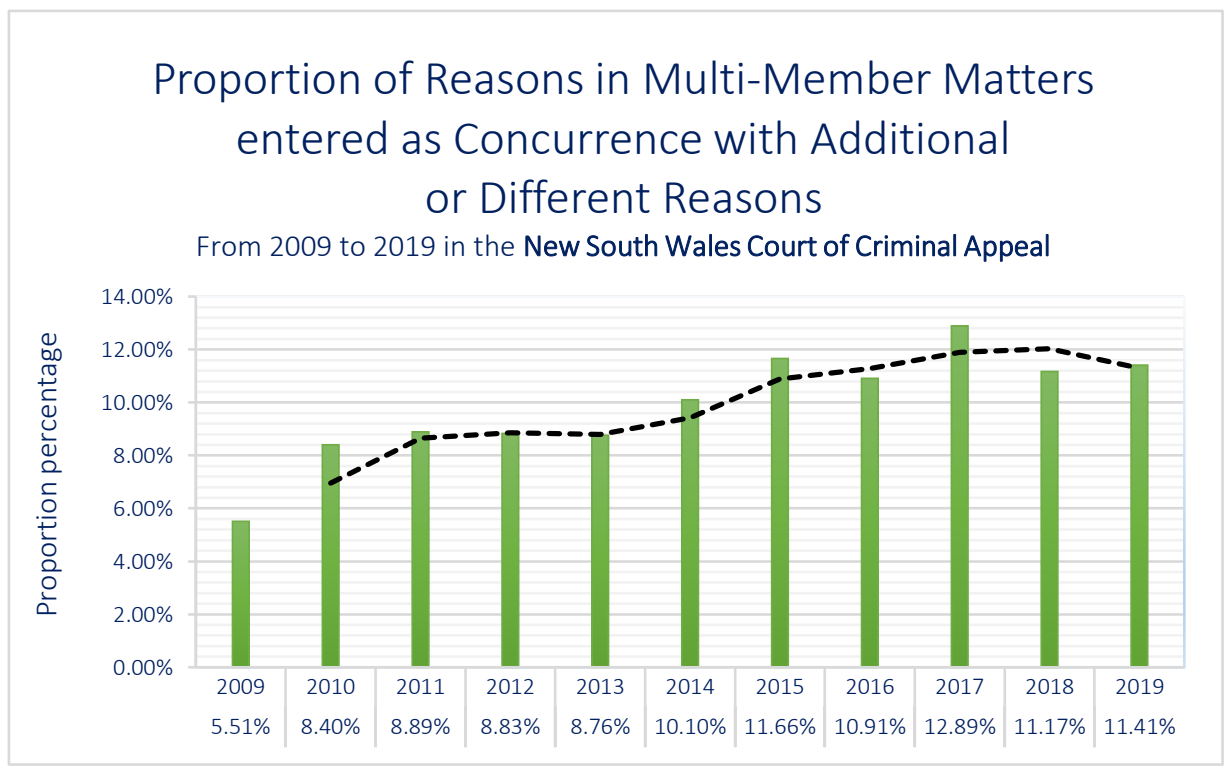

The proportion of NSWCCA reasons entered as concurrence but with additional or different reasons displayed gradual growth from 5.51 per cent in 2009 to 11.41 per cent to 2019.

\section{(d) NSWCCA: Discussion}

There is a very strong upward trend in the usage of joint judgments in the NSWCCA. Over nine years, joint judgments have emerged from an almost nonexistent way of entering reasons, to a somewhat recurrent feature in judgments. However, despite becoming much more prevalent in NSWCCA practice, joint judgments do not yet complement the Court's historically and presently dominant form of concurrence through the simple 'I agree' form with a single leading judgment. Indeed, in 2019, a separate concurrence with an 'I agree' was about five times more prevalent than joint judgments (9.59 per cent joint judgment proportion to a 47.86 per cent 'I agree' proportion). This statistic, however, is relevantly down from a concurrence with 'I agree' being almost 15 times more prevalent than a joint judgment in 2012 (3.65 per cent joint judgment proportion to a 53.64 per cent simple 'I agree' proportion). This highlights the 
rapid rate by which joint judgments have grown in NSWCCA practice, and how concurrence via 'I agree' is becoming less prevalent.

Like the NSWCA, a rise in joint judgments in the NSWCCA does not appear to reduce the prevalence of multiple substantive reasons. Instead, from 2009 to 2019, the prevalence of concurrences with additional or different reasons more than doubled.

\section{FCAFC}

\section{(a) Joint judgments}

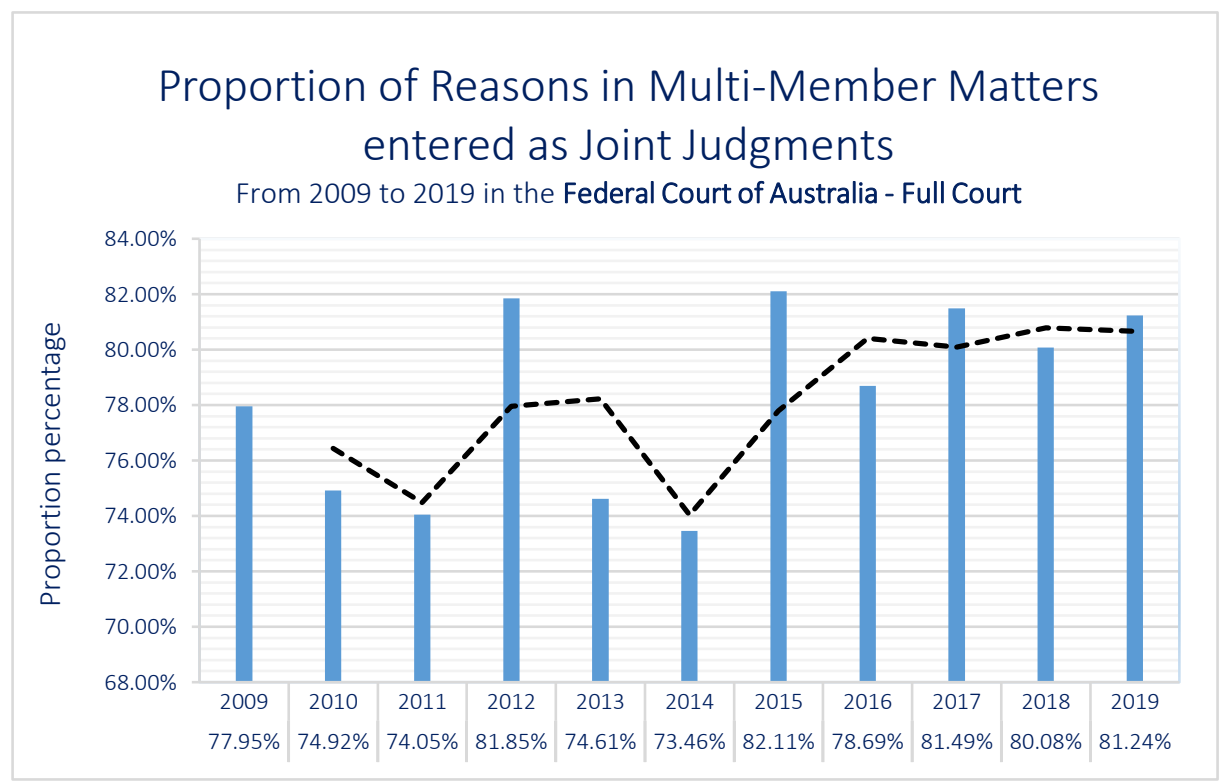

The proportion of FCAFC reasons entered as joint judgments has remained consistently very high. Only moderate volatility is observed, with a range between a low of 73.46 per cent in 2014 to a high of 82.11 per cent in 2015 . 
(b) Concurrence with 'I agree'

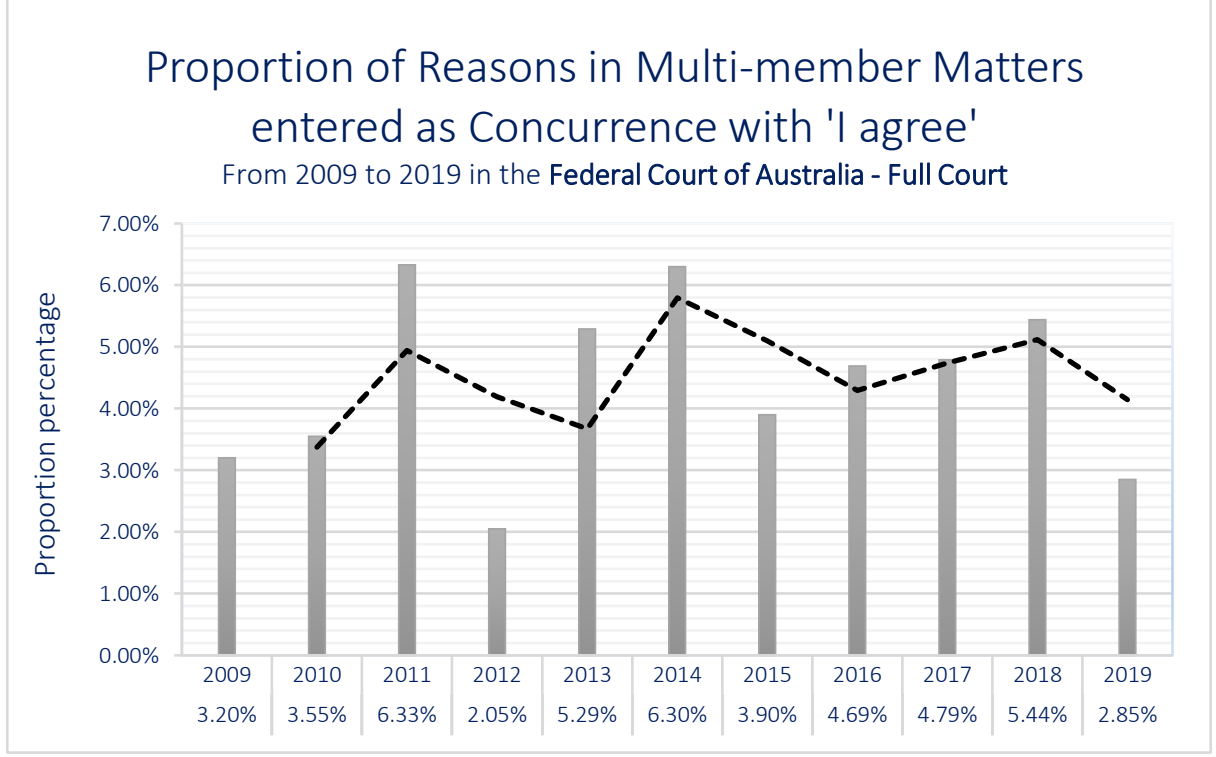

The proportion of FCAFC reasons entered in the simple form of 'I agree' has remained consistently very low. Only slight volatility can be seen, with a range between a low of 2.05 per cent in 2012 and a high of 6.33 per cent in 2011.

(c) Concurrence with additional or different reasons

\section{Proportion of Reasons in Multi-Member Matters entered as Concurrence with Additional or Different Reasons \\ From 2009 to 2019 in the Federal Court of Australia - Full Court}

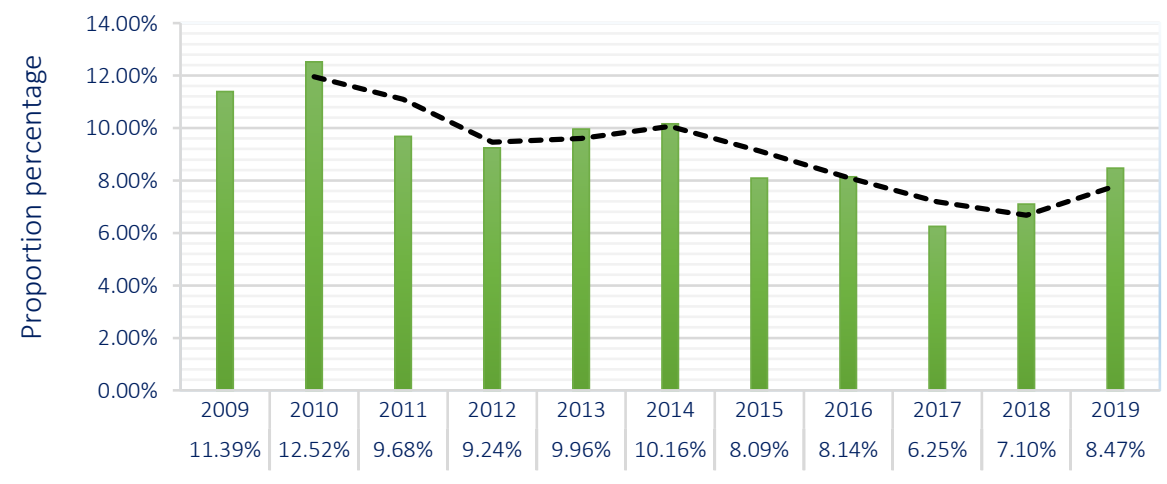


The proportion of FCAFC reasons entered as concurrence but with additional or different reasons dropped from a peak of 12.52 per cent in 2010 to a trough of 6.25 per cent in 2017.

\section{(d) FCAFC: Discussion}

Joint judgments are clearly the FCAFC's dominant form of entering reasons. Whilst acknowledging that courts cannot be characterised as 'monolithic institution[s]' with stable cultures and practices, ${ }^{89}$ the FCAFC's joint judgment use has been so consistently high from 2009 to 2019 that joined reasoning may be described with some accuracy as the Court's de facto institutional writing practice.

Contrastingly, it is rare for a judge presiding in a FCAFC matter to enter reasons as a concurrence with 'I agree'. Judges presiding in FCAFC matters clearly prefer to join in with the leading judgment if they find themselves in substantive agreement with it.

\section{General Discussion}

This study's empirical results demonstrate that in and before 2012, NSW intermediate appellate courts and the FCAFC presented diametrically different joint judgment practices. Judges within NSW intermediate appellate courts had a clear historical preference for individualism via multivocal and separate judgments. In times of concurrence in multi-member matters, NSW practice was for judges to separately assent, mostly through a simple 'I agree' statement. Meanwhile, the FCAFC strongly preferred joint judgments, where judges appear to have eschewed individualism in favour of an institutional judgment.

However, this study illustrates a striking upward trend from 2012 in joint judgment use in NSW intermediate appellate courts, with both the NSWCA and NSWCCA demonstrating approximately quadruple growth in their joint judgment usage from 2011/2012 to 2018. Some difference in joint judgment practice remains between these two intermediate appellate courts. In the NSWCA, joint judgments in 2019 were used just as frequently as concurrence with 'I agree', but a judge sitting in a NSWCCA matter was still far more likely to enter a separate 'I agree' than to join in with a leading judgment. Nevertheless, despite significant growth in joint judgment usage, NSW appellate court decision-making still strongly contrasts with the FCAFC, where, from 2009 to 2019, judges have consistently used joint judgments as their dominant writing practice.

89 Sir Anthony Mason, 'Foreword' in Haig Patapan, Judging Democracy: The New Politics of the High Court of Australia (Cambridge University Press, 2000) viii, viii. 
In both the NSWCA and NSWCCA, expressing reasons through a simple individual 'I agree' statement has reduced as joint judgments have become more prevalent. What has not reduced over time is the prevalence of concurring judgments with additional or different reasons. Rather, across each of the NSWCA, NSWCCA, and FCAFC, the proportion of reasons in the form of concurrence with substantive reasons has remained commonplace. Even in the FCAFC, where joint judgments normally reach an $\approx 80$ per cent proportion of reasons, concurrence with additional or different reasoning persists as a regular form of entering reasons. Thus, there appears to be no apparent correlation between an increase in joint judgment use and a decrease in separate additional or different reasons that concur with the leading judgment. This statistic could also indicate that 'unnecessary' concurring judgments with different or additional reasons do not reduce commensurately with an increase in joint judgment use, as Chief Justice Kiefel may have hoped. ${ }^{90}$ It might also suggest that there will always be a point to which judges who otherwise concur with the leading judgment's orders cannot compromise or negotiate their reasoning into that leading judgment, and thus turn to authoring a separate concurring opinion.

Ultimately, in 2012, a jurisdictional contrast in joint judgment use was apparent, where NSW courts opted for individual judgments and the FCAFC tended to a much higher expression of joint judgments. Over nine years, NSW intermediate appellate courts demonstrate a strong trend towards joining in over separately concurring, and as such joint judgments have become much more prevalent. In the light of this trend, NSW intermediate appellate court judges would appear to face a normative choice: to either continue growing joint judgment use so that it becomes the dominant form of entering reasons, complement joint judgments with separate concurrences, or reverse the trend back towards individualism and the dominance of separate reasons.

\section{AdDREssing President BeAZley's CuRiosity}

With a sustained surge in joint judgment usage in NSW intermediate appellate courts, there is immediate significance in addressing Beazley's 'curiosity' on the normative aspects of judgment writing practice and in considering whether minimalist mechanisms like joint judgments should be increasingly utilised. If members of NSW appellate courts decide to readily accept the applicability and relevance of Justice Kiefel's proposition of joint judgment usage as any appeal court's 'institutional responsibility', ${ }^{91}$ observers should reasonably expect higher uniformity and a push toward greater joint judgment usage similar to the FCAFC's $\approx 80$ per cent proportions. Indeed, FCAFC judges would likely see congruity with

Kiefel, 'Judicial Methods in the $21^{\text {st }}$ Century' (n 3) 4, 6-7.

Kiefel, 'The Individual Judge' (n 2) 560. 
their practices and Chief Justice Kiefel's arguments, with strikingly high joint judgment rates emphasising institutional acceptance and a strong adherence to the mode of judicial expression. However, should members of the NSW appellate cluster and other jurisdictions decide to view intermediate appellate courts as functionally distinct to the HCA and dismiss the HCA debates as idiosyncratic to that Court, one might expect HCA practices to have minimal or no implications on those intermediate appellate courts. Alternatively, intermediate appellate courts could share some functional similarities but also several differences with the HCA. Under this view, whether the move towards joint judgments in the HCA has relevance to intermediate appellate courts would depend on the nature of the shared characteristics between an intermediate appellate court and the HCA, and if they are sufficiently proximate to warrant potential comparison.

Consequently, the first step in assessing the implications of the HCA's practices is to examine the degree to which intermediate appellate courts such as the NSWCA, NSWCCA, and the FCAFC have functional similarity to the HCA.

\section{A Characterising Intermediate Appellate Court Functions}

Courts within Australia may express two functions in exercising judicial power. ${ }^{92}$ The first is a disposition function, whereby courts apply the law to either initially resolve a matter or, in the case of appeal courts, to correct an error or affirm a decision from a court lower in the hierarchy. The second is a developmental (or declaratory) function, in that a court's judgment contributes to the common law by, for example, clarifying procedure, extracting the meaning of statutes, or making policy determinations according to law. ${ }^{93}$

Courts vary in how they exercise these two functions. For example, the Local Court of NSW, being a trial and fact-finding court that hears hundreds of thousands of matters without need for leave, ${ }^{94}$ would focus almost exclusively on its disposition function. Its declaratory function would be extremely limited, given its inability to form substantive and binding precedent, and the fact that most Local Court judgments are unpublished, often cursory, and delivered ex tempore. ${ }^{95}$ The HCA, meanwhile, as Australia's apex court, which accepts only

See especially President James Allsop, 'Appellate Judgments - The Need for Clarity' (2010) 9(4) The Judicial Review 403, 403 ('Appellate Judgments'); Justice Ronald Sackville, 'Why Do Judges Make Law? Some Aspects of Judicial Law Making' (2001) 5(1) University of Western Sydney Law Review 59; Michael McHugh, 'Law Making in an Intermediate Appellate Court: The New South Wales Court of Appeal' (1987) 11(2) Sydney Law Review 183, 184-5.

93 See generally Richard S Kay, 'Judicial Policy-Making and the Peculiar Function of Law' (2007) 26(2) University of Queensland Law Journal 237.

94 See Local Court of New South Wales, Annual Review 2019 (Review, 2020) 17, 20 $<$ https://localcourt.nsw.gov.au/documents/annualreviews/Local_Court_Annual_Review_2019_v1_accessible.pdf $>$.

95 See, eg, Mortimer (n 73) 284. 
tens of cases a year on legal significance grounds, ${ }^{96}$ can be functionally juxtaposed with the Local Court. Naturally, the HCA must utilise its dispositive functions. However, the HCA would have a much more considerable and concentrated focus on its declaratory functions to proclaim Australian law authoritatively and conclusively. Thus, because the Local Court and HCA exercise their functions dichotomously, it would be, for example, an erroneous endeavour to say that HCA judgment writing practices should apply to the Local Court of NSW.

On intermediate appellate courts, Federal Court Chief Justice James Allsop submits that they have an 'important role' in espousing 'doctrines and conceptions concerning our constitutional and institutional freedoms'. ${ }^{97}$ However, when President of the NSWCA, he argued that an intermediate appellate court's dispositive function 'outweighs' its declaratory role, and that the situation is 'vice versa' for the HCA. ${ }^{98}$ If his Honour's supposition holds true, and the functions of the HCA and intermediate appellate courts are sufficiently asymmetric, then the HCA's debates on joint judgments would have little relevance to intermediate appellate court practice.

President Beazley also raises questions over whether the declaratory function of intermediate appellate courts is proximate to the HCA, stating that middle courts of appeal 'do not have the same constitutional function as the High Court, and there remains debate as to their declaratory role in the development of law'. 99 Clearly, the HCA, as Australia's federal supreme court, provides highly visible and impactful declarations of law, to the extent that a HCA majority judgment's 'seriously considered' obiter dicta constitutes binding precedent upon all lower courts. ${ }^{100}$ There are certainly persistent questions on the degree to which intermediate appellate courts can actively develop the law. Indeed, as Mortimer J identified, the FCAFC's 'law announcing' or declaratory function is 'not freestanding', because any legal development must be to 'resolve the application of law to facts existing in a dispute' and also satisfy the HCA, if a matter is appealed, that the law has been applied and developed correctly. ${ }^{101}$ In other words, the declaratory powers of intermediate appellate courts are restricted through the final court's oversight and also the opportunities presented by the issues raised in a particular matter.

See High Court of Australia, Annual Report: 2018-19 (Report, 2019) 5, $9<$ https://cdn.hcourt. gov.au/assets/corporate/annual-reports/HCA_Annual_Report_2018-19.pdf $>$.

Chief Justice James Allsop, 'The Role and Future of the Federal Court within the Australian Judicial System' (Speech, 40th Anniversary of the Federal Court of Australia Conference, 8 September 2017) 2. <https://www.fedcourt.gov.au/digital-law-library/judges-speeches/chief-justice-allsop/allsop-cj20170908\#>.

Allsop, 'Appellate Judgments' (n 92) 404-5.

Beazley (n 1) 82.

See Farah Constructions Pty Ltd v Say-Dee Pty Ltd (2007) 230 CLR 89, 150-1 [134] ('Farah'); Chief Commissioner of State Revenue v Benidorm Pty Ltd (2020) 104 NSWLR 232, 253 [103] (Leeming JA). Mortimer (n 73) 284-5. 
However, I would ultimately argue that Australian intermediate appellate courts and the HCA are sufficiently similar in their functions to enable fair and proper comparisons of their practices. Intermediate appellate courts are, of course, different to the HCA, and will, as Chief Justice Allsop identified, have varying focuses and operational needs. However, I would argue that the nature and degree of the functional similarities between middle courts of appeal and the HCA are enough to say that the HCA's trends and debates on joint judgments have relevance to intermediate appellate court writing practices.

Like the HCA, intermediate appellate courts are superior courts of record ${ }^{102}$ and may exercise their appellate jurisdiction in equity and at common law, ${ }^{103}$ demonstrating jurisdictional congruity between intermediate appellate courts and the HCA. Indeed, when he was Commonwealth Attorney-General (1958-64), Sir Garfield Barwick advocated for a Federal Court that would 'relieve' the HCA of its workload, ${ }^{104}$ especially in the HCA's original jurisdiction. ${ }^{105}$ According to Beaumont, Sir Garfield's view 'prevailed'. ${ }^{106}$ This reflection emphasises that despite the obvious hierarchy, the HCA and Federal Court are foundationally analogous.

The unanimous HCA decision in Farah Constructions Pty Ltd $v$ Say-Dee Pty Ltd ('Farah') ${ }^{107}$ exemplifies the significance of an intermediate appellate court's declaratory function and emphasises symmetry in the functional operations between middle courts of appeal and the HCA. In Farah, the Court held that if an intermediate appellate court interprets a Commonwealth law or uniform legislation in a certain way, or propounds any non-statutory law, its ratio is binding upon all courts in other Australian jurisdictions, including other intermediate appellate courts, unless the ratio is 'plainly wrong'. ${ }^{108}$ This is because intermediate appellate court decisions are integral to the 'common law of Australia'. ${ }^{109}$ Allsop CJ notes that the Farah requirement for intermediate appellate courts to follow decisions of other Australian courts of co-ordinate jurisdiction recognises a 'national integrated legal system and one Australian common law'. ${ }^{110}$ Thus, how an intermediate appellate court decides to shape

See, eg, High Court of Australia Act 1979 (Cth) s 5; Federal Court of Australia Act 1976 (Cth) s 5(2); Supreme Court Act 1970 (NSW) s 22.

See, eg, Federal Court of Australia Act 1976 (Cth) s 5(2); Supreme Court Act 1970 (NSW) s 44.

Chief Justice Garfield Barwick, 'The Australian Judicial System: The Proposed New Federal Superior Court' (1964) 1(1) Federal Law Review 1, 3.

Ibid 15.

Justice Bryan Beaumont, 'Federal Court of Australia' in Tony Blackshield, Michael Coper and George Williams (eds), The Oxford Companion to the High Court of Australia (Oxford University Press, 2001) 272, 272.

Farah (n 100).

See especially Antonia Glover, 'What's Plainly Wrong in Australian Law? An Empirical Analysis of the Rule in Farah' (2020) 43(3) University of New South Wales Law Journal 850.

Farah (n 100), 151-2 [135].

Minister for Immigration, Citizenship, Migrant Services and Multicultural Affairs v FAK19 [2021] FCAFC 153, [5] (Allsop CJ). 
certain laws has the same legal effect on every jurisdiction in Australia, almost as if the HCA itself had made that decision. In other words, the declaratory function of intermediate appellate courts is substantial and, aside from the HCA's final authoritative reviewing of intermediate decisions, symmetrical in effect to the HCA. As Justice Steven Rares of the Federal Court emphasises, all Australian intermediate appellate courts play undeniably major roles in the incremental development of the general 'unwritten law':111 they create most of Australia's precedent, and it is 'essentially unrealistic' to expect the HCA to oversee the 'development of the whole of Australian law' .112

Indeed, like the HCA, intermediate appellate courts must utilise their developmental function as if they were the final voice in a matter. Stewart and Stuhmcke studied the 783 applications for special leave to the HCA from 1 March 2013 to 3 February 2015. They found that only 10.22 per cent of applications (80 matters) were successful. ${ }^{113}$ For the 89.78 per cent of refused applications for special leave (703 matters), and for the entirety of judgments from intermediate appellate courts that were not appealed to the HCA, any law declared in those judgments formed part of the binding common law of Australia until, and if, the HCA says otherwise. ${ }^{114}$ Justice Robert Sharpe, a judge of the Court of Appeal for Ontario in Canada, confirms that intermediate appellate courts 'do decide many precedent-setting appeals' and 'do have a significant law-making role'. He submits that when a decision of an intermediate appellate court is 'not appealed, or leave to appeal is denied', their 'role is not unlike that of the Supreme Court [of Canada]' or an apex court in developing the law. ${ }^{115}$ Justice Banks-Smith emphasises that intermediate appellate courts, similar to the HCA, focus 'very much on the law and whether there has been an error below', not only to dispositively correct errors of law, but to discern and declare what the law is. ${ }^{116}$

Despite some debate about Farah's general desirability, ${ }^{117}$ the HCA decision nevertheless emphasises that intermediate appellate courts, similar to the HCA, place great emphasis on their declaratory function to substantively develop the common law of Australia.

(The Role of the Intermediate Appellate Court after Farah Constructions' (Speech, 4th Appellate Judges Conference of the Australasian Institute of Judicial Administration, 7 November 2008) $11<$ https://www.fedcourt.gov.au/digital-law-library/judges-speeches/justice -rares>.

$112 \quad$ Orr (n 26) 297

11 Pam Stewart and Anita Stuhmcke, 'Litigants and Legal Representatives: A Study of Special Leave Applications in the High Court of Australia' (2019) 41(1) Sydney Law Review 35, 36-8.

${ }^{114} \quad$ See Oliver Jones, 'Are the High Court's Reasons for Refusing Special Leave Binding?' (2013) 87(11) Australian Law Journal 774 for discussion on whether the High Court's seriously considered reasons for refusal of special leave, if provided, constitute binding precedent. At 782, Jones concludes that ' $[t]$ he preponderance of authority suggests that the High Court's reasons for refusing special leave are not binding. They merely offer guidance to lower courts'.

Banks-Smith (n 77) [18]-[19].

See, eg, Rares (n 111) 10-12. 
As President Beazley points out, intermediate appellate courts do not have the same constitutional regimes as the HCA. However, Farah demonstrates that these constitutional arrangements do not irreparably differentiate intermediate appellate court declaratory functions from those of the HCA. For example, sitting Federal Court judges actively examine not only 'what the High Court is writing' but 'what the Full Court [of the Federal Court] is writing' and 'comparable intermediate courts around the country - the state Supreme Courts and their Courts of Appeal' for binding precedent. ${ }^{118}$ While the HCA must declare law with a sense of finality, it is not prudent, according to former NSW Chief Judge at Common Law Peter McClellan, to believe that the 'latest judgment from the High Court in a particular area has finally explained the law and it will not require reexamination or revision'. ${ }^{119}$ McClellan emphasises the common constitutional requirement of Australian courts of superior record to identify legal deficiencies, opportunities, and 'contemporary community needs' through the dispute resolution process. ${ }^{120}$

Nevertheless, one key functional difference between intermediate appellate courts and the HCA is found in court workload. While the HCA can triage matters through special leave determinations, intermediate appellate courts generally face less decisional autonomy over which cases they can hear, resulting in higher case volumes and increased pressures to turnover judgments. ${ }^{121}$ Potentially, such pressures could practically reduce an intermediate appellate court's capacity to proclaim the law. The HCA, meanwhile, has a lower caseload, exercises a 'very high level of control' over its matters, and has considerably more time to consider cases before it and develop the law. ${ }^{122}$

However, I would argue that both courts share a pressure to exercise their functions in a timely manner. Indeed, the HCA itself held that '[s]peed and efficiency, in the sense of minimum delay and expense, are seen as essential to a just resolution of proceedings'. ${ }^{123}$ Justice Kiefel explicitly included the HCA in her statement that ' $[\mathrm{m}]$ ost appellate courts are subject to the pressures of time', and stated that 'our system of justice could not tolerate each judge writing independently in every case'. ${ }^{124}$ Baron Neuberger believes that both apex and intermediate appellate court pressures to speedily dispense with cases 'ha[s]

Mortimer (n 73) 288.

Justice Peter McClellan, 'Courts in the $21^{\text {st }}$ Century: Should We Do Things Differently?' (Speech, Australian Court Administrators Group Conference, Courts and Tribunals in the Community: The Role of Administrators, 24 November 2005) $1<$ https://www.supremecourt.justice.nsw.gov.au/ Documents/Publications/Speeches/Pre-

2015\%20Speeches/McClellan/mcclellan_2005.11.24.pdf>.

Ibid 8.

Justice Stephen Gageler, 'Why Write Judgments?' (2014) 36(2) Sydney Law Review 189, 201.

Ibid.

Aon Risk Services Australia Ltd v Australian National University (2009) 239 CLR 175, 213 [98]

(Gummow, Hayne, Crennan, Kiefel and Bell JJ).

Kiefel, 'The Individual Judge' (n 2) 556. Cf Gageler (n 121). 
never been greater', and he attributes this to the 'smaller and more international' world with increasingly 'sophisticated ... electronic developments'. ${ }^{125}$ While the HCA ordinarily has more time to consider disputes than intermediate appellate courts, I submit that there is similarity between the HCA and intermediate appellate courts in needing to dispose of matters without unnecessary delay, and, potentially, in finding practices that might increase judgment writing efficiency. I would further argue that the comparatively pronounced pressure on intermediate appellate courts to manage their workloads does not create sufficient asymmetry in dispositive function to say that court judgment writing practices should not be compared.

In summary, while the HCA's more visible, finite, and relatively unrestricted declaratory function separates it from intermediate appellate courts, there is still substantial similarity in their developmental functions as both intermediate appellate courts and the HCA congruously shape the common law of Australia. Both courts also share symmetry in their dispositive functions by reviewing, as courts of superior record, decisions of lower courts in a timely manner. Intermediate appellate courts, however, do experience greater pressure than the HCA to manage and process their workloads, to the extent, as Chief Justice Allsop suggests, that their dispositive responsibility outweighs their declaratory role. However, I would not consider that these differences meet a threshold required to render any comparison inappropriate. Instead, I would say that the key characteristics of intermediate and apex court functions in Australia are sufficiently similar to deem the HCA's developments and arguments on judgment writing as relevant to the practices of intermediate appellate courts.

\section{B Addressing the Implications: Should Judges of Intermediate Appellate Courts Preference Joint Judgments?}

One of the principal arguments for joint judgments is that, by bringing judges together, the court's reasons are 'more conducive to clarity'. ${ }^{126}$ The legal certainty and authority underpinned by joint judgments, according to Justice Keane, better 'fulfil' an appellate court's 'duty to the development of the law'.127 Justice Keane proposes, for example, that the influence of Amalgamated Society of Engineers $v$ Adelaide Steamship Co Ltd ${ }^{128}$ comes not from the quality of the HCA's reasons or its language, but rather the 'unified statement of [the Court's] position' through the joint judgment expression. ${ }^{129}$

\footnotetext{
Neuberger, 'Sausages and the Judicial Process' (n 19) [39]

Keane (n 4) 15.

Ibid 15-16.

(1920) 28 CLR 129.

Keane (n 4) 17.
} 
By presenting a unified message instead of multiple distinct opinions, joint judgments may also improve 'access to justice'. ${ }^{130}$ Shorter joined reasons assist judgment consumers, such as legal practitioners and judicial officers, to more readily understand the law and apply or advise it.131 Thus, 'downstream' stakeholders, including litigants, enjoy benefits such as reduced legal fees. ${ }^{132} \mathrm{Sir}$ Frank Kitto's remark that judges tend to 'rejoice' when discovering that a relevant precedent is expressed through joint judgment emphasises that the form engenders a degree of certainty and clarity that members of the profession appreciate. ${ }^{133}$ Conversely, judgments with separately authored reasons can often 'chagrin' readers 'who have to spend many hours sifting the sediment to find the gold[en]' ratio. ${ }^{134}$

While joint judgments may be perceived to offer greater clarity, I submit that legal certainty is not necessarily intrinsic to joined reasons. As Justice Dyson Heydon explains, the absence of alternative viewpoints does not mean that a joint judgment automatically instils greater certainty. ${ }^{135}$ Indeed, Baron Neuberger's argument that 'it is often positively helpful to have more than one judgment to take the debate forward' in areas like 'tort', ${ }^{136}$ emphasises that joint judgments can be rather undesirable by stalling legal development and clouding meaning in particular contexts.

Separately, Chief Justice Allsop's view that the 'explanatory power of language' has its 'limits' and that '[t]o truly understand some conceptions, description, context, evaluation and intuition need to be appreciated', ${ }^{137}$ emphasises that joint judgments have the capacity to underdeliver clarity, and that multiple well-considered reasons can enhance a reader's overall understanding of the court's opinion. In fact, according to Chief Justice Allsop, comprehensive 'context (human and legal) is critical' to understanding how 'lawyers and jurists ... impose certainty through the reduction of legal principle into textually expressed statements'. ${ }^{138}$ Multiple separate voices can, in many cases, better encapsulate context and consequently improve clarity.

Cosmas Moisidis, 'Achieving World's Best Practice in the Writing of Appellate Judgments' (2002) 76(10) Law Institute Journal 30, 35. See also Mortimer (n 73) 283.

See Enid Campbell, 'Reasons for Judgment: Some Consumer Perspectives' (2003) 77(1) Australian Law Journal 62, 64-5.

Moisidis (n 130) 32.

Sir Frank Kitto, 'Why Write Judgments' (1992) 66(12) Australian Law Journal 787, 797.

Michael Coper, 'Joint Judgments and Separate Judgments' in Tony Blackshield, Michael Coper and George Williams (eds), The Oxford Companion to the High Court of Australia (Oxford University Press, 2001) 367,368 ('Joint Judgments and Separate Judgments').

Heydon (n 44) 212.

Neuberger, 'Sausages and the Judicial Process' (n 19) [32].

Chief Justice James Allsop, 'Uncertainty as Part of Certainty: Appreciating the Limits of Definitional Clarity and Embracing the Uncertainty Inherent in Any Matter of Complexity' (Speech, Australian Academy of Science and Australian Academy of Law Joint Symposium, 23 August 2018) [5] <https://www.fedcourt.gov.au/digital-law-library/judges-speeches/chief-justice-allsop/allsopcj-20180823>.

Ibid [2]. 
The compromise often required for joint judgment can also prevent desirable legal development by shadowing alternatives ${ }^{139}$ and consequently 'impede rather than develop the law, and reduce its clarity and predictability'. ${ }^{140}$ The precise level of risk in whether a joint judgment potentially undermines the development of the common law, however, is unclear. Chief Justice John Doyle would characterise the risk as only 'slight'. ${ }^{141}$ Baron Neuberger, however, adopts a much stronger tone. He identifies that a judge's individually developed reasons 'can be jettisoned on the road to agreement', which he submits is rarely 'helpful' to the law because the result will not be reflective of the beliefs actually held by the court. ${ }^{142}$ The authority embedded within unified judgments may also not always be correct or long-standing: Justice Heydon critiqued both joint judgments and bare concurrences by pointing to the 1961 murder appeal of Director of Public Prosecutions $v$ Smith, ${ }^{143}$ where a speech delivered by Lord Kilmuir and concurred by all the presiding Law Lords has been regarded by '[v]ery few' as 'correct or clear'. ${ }^{144}$

Another argument for joint judgments is that the writing practice is more efficient than reasons delivered in seriatim. Joint judgments, and their often associated practice of collaborative conferences between judges to identify judicial synergies and negotiate compromises, are said to eclipse the problem of 'undisciplined individualism' that can reduce appellate work to 'mere confusion'. ${ }^{145}$ Justice Keane submits that the joint judgment writing process champions judicial professionalism over self-indulgence. ${ }^{146}$ He believes that the conferencing process to design a joint judgment considerably 'sharpens up' the overall quality of reasons, because the reasons benefit from three, five, or seven minds rather than one. ${ }^{147}$ Chief Justice Kiefel sees joint reasoning as one possible antidote to backlogs, stating that multiple reasons 'will at some point delay the court giving judgment' and diminish the court's reputation 'as a whole'. ${ }_{148}$

See discussion on the 'ripple effects' of opinion divergence in Kenneth J Kress, 'Legal Reasoning and Coherence Theories: Dworkin's Rights Thesis, Retroactivity, and the Linear Order of Decisions' (1984) 72(3) California Law Review 369, 380.

Baron David Neuberger, 'Developing Equity: A View from the Court of Appeal' (Speech, Chancery Bar Association Conference, 20 January 2012) 6 [22] ('Developing Equity') $<$ https://www.judiciary.uk/wp-content/uploads/JCO/Documents/Speeches/mr-speech-chancerybar-assoc-lecture-jan12.pdf>. See also Sarah Murray, 'The High Court on Constitutional Law: The 2016 Term' [2017] (2) University of New South Wales Law Journal: The Forum 1, 9.

Chief Justice John Doyle, 'Judgment Writing: Are There Needs for Change?' (1999) 73(10) Australian Law Journal 737, 739 .

Neuberger, 'Developing Equity' (n 140) 6 [22].

[1961] AC 290.

Heydon (n 44) 212.

Alfred Simpson, 'Lord Denning as Jurist' in JL Jowell and JP WB McAuslan, Lord Denning: The Judge and the Law (Sweet and Maxwell, London, 1984) 441, 451.

Keane (n 4) 19. See also Coper, 'Joint Judgments and Separate Judgments' (n 134).

Keane (n 4) 19.

Kiefel, 'The Individual Judge' (n 2) 556. See also Kiefel, 'Judicial Methods in the $21^{\text {st }}$ Century' (n 3) $8-9$. 
Indeed, the HCA's fast turnaround of unanimous judgments during the politically turbulent Australian federal parliament eligibility crisis ${ }^{149}$ was, in Lynch and Williams' view, 'highly valued'. 150

Collegiality and speed, though, come with costs. Lynch and Williams identify that the price of compromise may be elegance of expression and a judgment narrowed to the immediate issues. This may reduce creativity and create blandness. ${ }^{151}$ Sir Frank Kitto agrees that sometimes 'justice delayed is justice denied', but insufficiently done justice is 'manifestly' worse. ${ }^{152}$ His argument that it is often better that each judge 'individually, exactingly, intensely [put] in writing what the Judge believes ought to be said' ${ }^{153}$ emphasises that justice is frequently not about producing an authoritative or unanimous judgment, but rather about achieving the best judgment for the circumstances.

The joint judgment crafting process also has significant free-rider risks which can reduce an appeal court's general institutional utility. Sir John Latham identified such risks in 1950, stating that the consultative process which facilitates joint judgment writing may lead 'one judge to do all the work and really make up the mind of the Court'. ${ }^{154}$ In line with Sir Latham's observation, Justice Steven Gageler uses Condorcet's Theorem to demonstrate a potentially suboptimal effect of joint expression. He explains that if each appellate judge decides and reasons independently, the risk of judicial error is reduced, as three, five, or seven judges have thought through the problem in separate writing and arrived at the same, or a sufficiently similar, point. ${ }^{155}$ Meanwhile, if only one judge decides and reasons independently, and all other judges agree without a substantive reasoning process equal to the lead judge, the risk of an erroneous judgment is significantly increased. ${ }^{156}$ Justice Gageler also identifies the risk that, in a post-trial conference where judges discuss the possibility of joining together in judgment, judges are more likely to agree with a lead judge to avoid disapproval and to achieve intellectual conformity. The result, then, is judges joining to reasons that do not actually reflect what they think or what they could potentially think if they had undergone a substantive independent reasoning process, reducing not only judicial independence but the benefits from 'the de-correlation

See Paul Karp, 'Australia Citizenship Crisis Reignites as Senator and Four MPs Quit', The Guardian (online, 9 May 2018) <https://www.theguardian.com/australia-news/2018/may/09/australiacitizenship-crisis-reignites-as-senator-and-four-mps-quit> .

Andrew Lynch and George Williams, 'The High Court on Constitutional Law: The 2017 Statistics' (2018) 41(4) University of New South Wales Law Journal 1134, 1154 ('2017 Statistics'). See also Murray (n 140) 4. Cf McIntyre and Tutton (n 10) 40.

Lynch and Williams, '2017 Statistics' (n 150). See also Coper, 'Joint Judgments and Separate Judgments' (n 134).

Kitto (n 133) 790.

Ibid 798.

Clem Lloyd, 'Not Peace but a Sword!: The High Court under JG Latham' (1987) 11(2) Adelaide Law Review $175,186$.

Gageler (n 121) 196. Cf Keane (n 4) 19.

Gageler (n 121) 196. 
of individual error'. ${ }^{157}$ As Justice Heydon put it, '[i]t is wrong, then, for judges to abstain' from drafting separate reasons 'to seek to achieve the appearance of unity and uniformity'. ${ }^{158}$ Nevertheless, Justice Virginia Bell believes that judges accept 'responsibility' for 'subscrib[ing]' to a joint judgment, and she submits that the judge's name appearing in those reasons is sufficient accountability and transparency. ${ }^{159}$ However, I would note that the risks of suboptimal performance through free-riding and the application of behavioural tendencies to conform would still remain.

One final argument for joint judgments is that they are an effective counter to verbosity. ${ }^{160}$ Sir Frank Kitto concedes that appellate courts generally suffer from ' $[t]$ he menace of prolixity, irrelevant wandering and imprecision', and accepts that joined reasoning can sometimes reduce these features. ${ }^{161}$ Nevertheless, separate judgments are not the cause of verbosity and prolix, and joint judgments do not always alleviate a court of irrelevant or indulgent writing. Instead, as Justice Heydon puts it, a separate concurring opinion 'need not be a long separate opinion'.162 Mason also questions the utility in 'judicial minimalism', stating that it is an appeal court's duty to address contentious facts and law comprehensively and completely. ${ }^{163}$ Indeed, the risk of 'gnomic ... brevity' in a joint judgment is just as, if not more, detrimental as verbosity. ${ }^{164}$ As Bagaric and McConvill argue, treating courts like committees and pursuing the absolute prioritisation of direct relevancy over subtle nuance may 'transform the craft of judicial decision writing to something akin to the legislative writing process, where brevity and outcomes have long trumped purpose and reasoning' ${ }^{165}$

Ultimately, to address President Beazley's curiosities on the desirability of joint judgments, it appears that there is 'validity in both sides of [the] equation'. ${ }^{166}$ I would agree with Lynch that judgment writing is 'inherently something about which reasonable minds may differ', and thus a soft or hard protocol, rule, or principle on joint judgments is 'neither required nor possible'. ${ }^{167}$ Sir Frank Kitto agrees that no 'categorical answer ought to be attempted [on] whether and when a member of a multiple court is justified in simply concurring in a judgment written by a colleague', because 'there is no [one] way of writing judgments' ${ }^{168}$ Justice Kiefel herself concedes that 'it is not possible to state a rule,

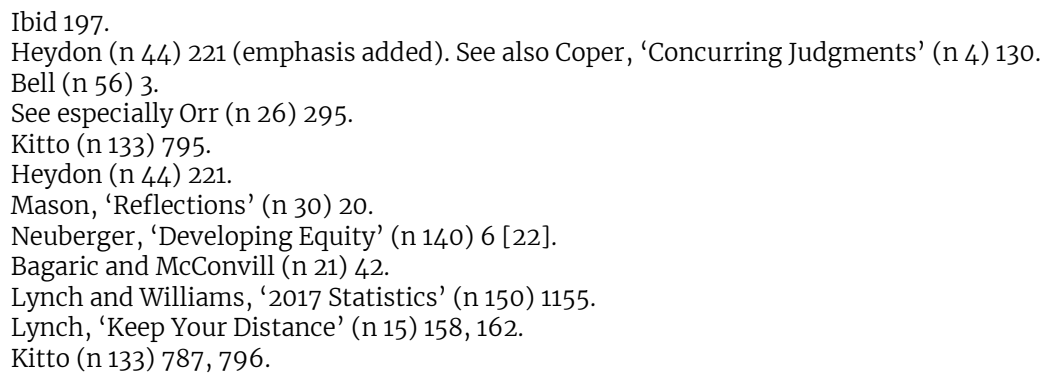


such as that each judge should write separately in every case', due to the undefinable list of instances a judge may find it preferable to write jointly or individually. ${ }^{169}$

In my view, a judge's choice in whether they opt for a formulaic writing approach, or whether they strive for elegance, or whether they generally prefer individualism against institutionalism or vice versa, is necessarily a personal decision. I argue that a judge should consider the possibility and the implications of a joint judgment in each case. However, to maximise judicial independence, a judge's consideration must not be disturbed by a pressure or procedure to join or separate. As Chief Justice Allsop emphasises, courts are human institutions, and as such, the 'human aspects of judicial life should dominate and pervade the institutional life and structures of the Court'. ${ }^{170}$

Having said this, a dalliance on a curiosity of my own is whether a current English method of judgment writing should have a place in Australian practice. In the Supreme Court of the United Kingdom, judges who wish to affix their name to a lead set of reasons are not necessarily listed as having written those reasons equally and jointly. ${ }^{171}$ Instead, they can be listed as having agreed with the lead author. For example, in Stoffel \& Co v Grondona, ${ }^{172}$ judges were listed as follows:

Lord Lloyd-Jones (with whom Lord Reed, Lord Hodge, Lady Black and Lady Arden agree)

In this case, Lord Lloyd-Jones wrote the Court's reasons and his colleagues provided simple assent.

Variations to this method are possible. Judges who offered substantial contributions but did not principally write the judgment could be listed as such. For example, a three-member hypothetical listing in the NSWCA could appear with the lead author first in bold, and then the concurring justices listed thereafter according to their contribution:

\section{Bathurst CJ}

with whom Bell $\mathrm{P}$ agreed and substantially contributed, and

with whom Meagher J agreed in full

169 Kiefel, 'The Individual Judge' (n 2) 555.

$170 \quad$ Chief Justice James Allsop, 'Courts as (Living) Institutions and Workplaces' (Speech, 2019 Joint Federal and Supreme Court Conference, 23 January 2019) 19 <https://www.fedcourt. gov.au/digital-law-library/judges-speeches/chief-justice-allsop/allsop-cj-20190123> ('Courts as Institutions').

171 Joint judgments can and still do occur in the Supreme Court of the United Kingdom. See, eg, Her Majesty's Attorney General v Crosland [2021] UKSC 15, where a judgment of the Court is issued. See also Ho v Adelekun [2021] UKSC 43 where judges were listed as follows: Lord Briggs and Lady Rose (with whom Lady Arden, Lord Kitchin and Lord Burrows agree). 
I speculate that this method could add some value to the judicial writing mix. First, it removes the need for imperfect methods such as 'computational linguistics' to detect which judge actually wrote joint reasons. ${ }^{173}$ It encourages judges to consent to colleagues 'join[ing] in' ${ }^{174}$ because the method does not anonymise individual efforts and thus, as Justice Kiefel notes, provides the lead author the 'simple pleasure' of acknowledgment. ${ }^{175}$ The proportionate allocation of acknowledgment also has the potential to alleviate free-riding and the impacts of heuristics. As Baron Neuberger observes, only 'saint[s]' would scrupulously contribute to a judgment that they do not receive credit for. ${ }^{176}$ If judges who, say, substantially contribute to a leading judgment receive acknowledgment, this method might improve court collegiality while encouraging healthy compromise without undermining independence. Finally, by bringing judges together, the style brings all the apparent authority, certainty, and clarity of a joint judgment without its dehumanising elements.

\section{CONCLUSION}

Commensurately with the HCA, NSW intermediate appellate court judges have increasingly accepted and used joint judgments from 2009 to 2019. This is a striking departure from NSW courts' historically dominant practice of entering reasons separately. Meanwhile, the rate at which FCAFC judges express their reasons in joined form is so consistently high that joint judgments can be described as the institution's dominant writing practice. Despite the difficulty in writing jointly, joint judgments are becoming more prevalent across the examined jurisdictions and, indeed, increasingly seen as potentially desirable.

Likely suspecting these trends, President Beazley asks what the implications should be for intermediate appellate courts. I would suggest that a practical consequence of this trend should not include a deliberate push towards a disciplined practice of entering joint judgments. Instead, joint judgments should complement separate concurrences in the judicial armoury.

In line with Chief Justice Kiefel's arguments, it is probably the institutional responsibility of appellate court members to consider writing jointly. But I would add that consideration is the appropriate threshold to satisfy institutional responsibilities, and that any requirement, expectation, or pressure to join in is manifestly undesirable. Joint judgments, in encapsulating an appeal court's voice, undoubtedly can, in some cases, deliver legal certainty, clarity in reasons,

Partovi et al (n 4). See also Yanir Seroussi, Russell Smyth and Ingrid Zukerman, 'Ghosts from the High Court's Past: Evidence from Computational Linguistics for Dixon Ghosting for McTiernan and Rich' (2011) 34(3) University of New South Wales Law Journal 984.

174

175

176

Kiefel, 'The Individual Judge' (n 2) 557.

Ibid.

Neuberger, 'Sausages and the Judicial Process' (n 19) [34]. 
and rapid judgment turnover. Joined reasons contribute, necessarily at times, to improved public perceptions of appeal courts as authoritative third arms of government that provide definitive, rather than confusing or fractured, declarations of law. Nevertheless, from as early as 1932, it has been prudently observed that 'humanity will stain the law reports until the courts are manned by Robots'. 177 In other words, differing perspectives, contributions, and processes of reasoning are, and should be, an enduring characteristic of multi-member courts. Separate reasons can, when appropriate, likewise add to clarity and certainty and, similar to a dissenting view, enable the court to explore different legal avenues that might later become preferable. What I have argued is that joint judgments and separate reasons each deliver benefits on different occasions, and thus there should be no formal or informal rule or principle that encourages judges to use one form over the other.

To describe my proposition plainly, a judge is the best judge on how to write their judgments. A judge's overriding responsibility is to apply their conscience and enter reasons in a way that they think best disposes of the specific dispute and develops the law. While appellate court judges should always consider the utility that a joint judgment could deliver in each case, their discretion to enter reasons separately should not, in my opinion, be curtailed.

As a final comment, potentially minimalist mechanisms such as joint judgments might maximise a court's efficiency. But if the price is 'a loss of human context, a loss of the expression of the human purpose of the law' ${ }^{178}$ perhaps the minimalist trend is one deserving serious attention and examination before judges ultimately decide to join in.

\section{APPENDIX}

The Excel spreadsheets containing the raw data used for 'Part III: Profile of Judgment Writing Practices' can be accessed in the hyperlink below. Please note that this hyperlink will direct you to a folder stored on the file hosting service 'Dropbox'. ${ }^{179}$

\section{https://www.dropbox.com/sh/g6zwzrc2ktfpu4a/AACB40C4rIougW004kC8wfG} Ua?dl=0

Cecil Fifoot, English Law and Its Background (G Bell and Sons Ltd, 1932) 249.

Allsop, 'Courts as Institutions' (n 170).

This hyperlink is functional at the time of publication. Please note, however, that as this archive is stored on a third-party service provider, the ongoing usability and accessibility of this archive may not be possible. 